\title{
NAS MARGENS DA ESTRADA E DA HISTÓRIA JURUÁ: UM ENSAIO SOBRE AS OCUPAÇÕES MBYÁ NA REGIÃO HIDROGRÁFICA DO GUAÍBÁ (ESTADO DO RIO GRANDE DO SUL)
}

\author{
CÉSAR CASTRO PEREIRA ${ }^{1}$ \\ UFRGS
}

MARIA PAULA PRATES ${ }^{2}$

UFRGS

\begin{abstract}
RESUMO: Neste ensaio buscamos sistematizar informações de cunho histórico e etnográfico acerca da presença mbyá na região hidrográfica do Guaíba (Rio Grande do Sul/Brasil), levando em conta as relações estabelecidas entre indígenas e brancos ao longo do processo de configuração territorial da Bacia Platina. Embasamos a discussão a partir de pesquisa de campo, levantamento bibliográfico e fontes primárias acerca de três ocupações mbyá contemporâneas, a saber, Petim, Passo Grande e Arroio do Conde.
\end{abstract}

PALAVRAS-CHAVE: Mbyá-Guarani; Territorialidade; Alianças circunstanciais.

ABSTRACT: In this article we seek to systematize historical and ethnographic informations about mbyá presence in the Guaíba hydrographic area (Rio Grande do Sul/Brazil), taking into account the relations between indians and non-indians through the process of territorial configuration of Bacia Platina. This discussion is based on fieldwork, literature and primary sources about three contemporary mbyá occupations -- Petim, Passo Grande and Arroio do Conde.

KEYWORDS: Mbyá-Guarani; Territoriality; Circumstantial alliances.

\footnotetext{
${ }^{1}$ Mestrando em História pelo Programa de Pós-Graduação em História da Universidade Federal do Rio Grande do Sul (PPGH/UFRGS). E-mail: maria.prates@ufrgs.br .

2 Doutoranda em Antropologia Social pelo Programa de Pós-Graduação em Antropologia da Universidade Federal do Rio Grande do Sul (PPGAS/UFRGS). E-mail: cesarcpereira@ hotmail.com .
} 
Neste ensaio ${ }^{3}$ buscamos sistematizar informações de cunho histórico e etnográfico acerca da presença mbyá ${ }^{4}$ na região hidrográfica do Guaíba (Rio Grande do Sul), levando em conta as relações estabelecidas entre indígenas e brancos ao longo do processo de configuração territorial da Bacia Platina. Para tanto, embasamos a discussão a partir de pesquisa de campo, levantamento bibliográfico e fontes primárias acerca de três ocupações mbyá contemporâneas, a saber, Petim, Passo Grande e Arroio do Conde. As duas primeiras, teko'a Arasaty (Arroio Petim) e Nhüu Poty (Passo Grande), contam com a presença de famílias indígenas desde, no mínimo, as décadas de 1960 e 1970. Suas moradias situam-se próximas à BR-116, entre os municípios gaúchos de Guaíba e Barra do Ribeiro, rodovia com maior distância longitudinal do Brasil e com grande tráfego diário. Takuaty Porã (Arroio do Conde), por sua vez, encontra-se compulsoriamente desocupada desde 2008, quando os Mbyá conseguiram acessar a área de modo permanente por alguns meses, mas foram retirados pela Brigada Militar em cumprimento de ação de reintegração de posse ${ }^{5}$. Esta última ocupação ocorreu nas margens da estrada estadual do Conde, no limite entre os municípios de Eldorado do Sul e Guaíba (RS).

Miramos, portanto, dois objetivos: 1. Reunir informações existentes e dispersas em vários documentos a fim de contextualizar ocupações guarani na Bacia Hidrográfica do Guaiba; 2. Ressaltar as circunstâncias atuais de ocupações em beiras de estradas sob premissas diacrônicas, evidenciando a vida mbyá nos teko'a ${ }^{6}$ e ensaiando algumas considerações a respeito das alianças circunstanciais acionadas no acesso ao território.

\footnotetext{
${ }^{3}$ Gostaríamos de agradecer a Bruno Ribeiro Marques, que participou da pesquisa de campo e bibliográfica, e a Miriam Furtado Hartung pela leitura atenta e considerações feitas ao presente ensaio. ${ }^{4}$ Os indígenas da etnia Mbyá-Guarani pertencem, linguisticamente, ao tronco Tupi, família Tupi-Guarani, dialeto Mbyá. Nos dias atuais ocupam uma longa faixa territorial, incluindo desde os estados do Sul e Sudeste do Brasil, como RS, SC, PR, SP, RJ, ES, e norte do estado do PA até países como Uruguai, Argentina e Paraguai. Entre os Mbyá-Guarani, todos são falantes da língua nativa e grande parte das mulheres e crianças são monolíngues guarani. Somam cerca de três mil pessoas no estado do Rio Grande do Sul, distribuídas em aproximadamente vinte e duas aldeias. Enquanto subgrupo guarani, os Mbyá são conhecidos nos estudos etnológicos por sua prática de deslocamento territorial.

5 Ação de Reintegração de Posse impetrada pela Fundação Estadual de Pesquisa Agropecuária (FEPAGRO).

${ }^{6}$ Em termos nativos, os significados para o termo teko'a ultrapassam a compreensão de espaço físico. Em contexto de regularização fundiária é utilizado para referenciar espaços ocupados, manejados e importantes desde o ponto de vista cosmológico e, por esse motivo, muitas vezes é traduzido pelos Mbyá, a fim de serem compreendidos pelas instâncias governamentais, como "aldeia".
} 
Sucessivas guerras envolvendo interesses divergentes entre Coroa Espanhola e Portuguesa no início da colonização europeia desenharam as fronteiras do sul do Brasil. A imposição de fronteiras estatais aos Guarani forçou-os a adequarem-se durante muitos anos à oferta disponível de espaços. As Reduções missioneiras, a Guerra Guaranítica, a Guerra do Paraguai, a Revolução Farroupilha e Federalista são alguns dos eventos marcantes ocorridos ao longo do tempo. Em sua grande maioria, foram arregimentados para lutarem nas guerras e também para fixarem-se nas Missões. Outros conseguiram resistir às Reduções jesuíticas e às guerras escondendo-se nas matas de floresta atlântica na região da fronteira entre Argentina e Paraguai. Outros, ainda, conseguiram sobreviver em regiões já colonizadas por brancos através de alianças locais/circunstanciais, a exemplo do que se pode observar nos registros de batismo, nascimento, óbito e de polícia envolvendo indígenas guarani na região de Porto Alegre, Guaíba e Barra do Ribeiro (municípios do RS).

A permanência mbyá, nas últimas décadas, em teko'a como Arasaty e Nhüu Poty tornou-se possível devido às alianças com moradores do entorno, que reverberaram em troca de favores, doação de alimentos e roupas, ocasionando uma convivência relativamente tranquila. Observa-se uma discursividade recorrente por parte dos juruá (brancos, não indígenas) vizinhos às ocupações em afirmar que os Mbyá não incomodam e não costumam desencadear conflitos. Também enfatizam os Mbyá que não afrontam e não contrariam as orientações dos juruá, sendo respeitosos aos domínios das cercas. O fato de manifestarem-se cordiais em relação aos juruá não implica na aceitação de restrição de uso do espaço, reconhecido por estes como seu território ancestral; e nem de concordância com o pensamento dos brancos. No dia a dia do trabalho de campo e a partir de uma escuta atenciosa foi possível compreender que as narrativas nativas em espaços públicos - e quando o interlocutor juruá não era reconhecido 
como aliado - apontavam para esse trato amistoso e de "respeito"7, ao passo que as práticas de uso e manejo do território, ademais de cercados, faziam-se presentes no cotidiano do teko'a. Sabem os Mbyá que essas alianças são circunstanciais e importantes para o acesso aos recursos ambientais disponíveis e também para que permaneçam próximos ao território tradicional. Sendo assim, utilizam-se de estratégias que garantem o acesso, mesmo que parcial, como trilhas por dentro da mata ciliar, para alcançar vertentes d'água, colocar mondéu e mondepi (armadilhas para capturar animais), coletar material para artesanato e ervas medicinais.

José de Souza, liderança política do teko'a Arasaty, recorda-se de situação "triste" envolvendo ele e outros Mbyá na ocasião em que pescavam em açude próximo ao Arroio Petim, no ano de 2002. Os proprietários juruá acionaram a Brigada Militar, que os interpelou solicitando esclarecimentos sobre o porquê e como haviam adentrado as cercas. José contou que o "sargento" os abordou amistosamente e aconselhou que evitassem pescar no local, não registrando Boletim de Ocorrência. Ao concluir a narrativa do episódio, enfatizou que há pouco peixe por conta das extensas lavouras de arroz e que nos poucos lugares onde a pesca ainda é possível, os Mbyá estão com acesso restrito. "Os juruá têm ciúme da terra", resume José.

O sentimento de posse e de disputa por espaço territorial não é bem visto pelos Mbyá, que entendem que Nhanderu fez o atual mundo para que todos pudessem usufruí-lo. Os eventos de conflito e que causam sentimentos de tristeza não devem ser contados a fim de evitar que continuem a causar malefícios. Sobre episódios como esse de interpelação pela Brigada Militar, encontramos o tom amenizador e enfático de pontos vistos como positivos, como o de não registrar ocorrência e o de uma abordagem cordial. Conta-se o acontecido, mas deixa-se de explicitar os sentimentos entendidos como "ruins".

Em relação à Arroio do Conde, nas décadas de 1960 e 1970, as narrativas sobre as desocupações tenderam a ser apaziguadas pela afirmação "não tava bom pro guarani ficar", como dito por Benito de Oliveira (aldeia de Araquari/SC, abril de 2010). A narrativa de Feliciano

\footnotetext{
7 Aspas são utilizadas para palavras e frases ditas em português pelos Mbyá, bem como para palavras e frases ditas por entrevistados brancos.
} 
Benitez, que também viveu em Arroio do Conde na década de 1970, explica:

Naquele tempo não tinha vila. Tinha morador. Faz 20 ou 30 anos. Tinha vizinho bom, proseava. Sempre onde mora tem opy (casa de reza), sempre fazia nossa casinha. Fazia opyzinho. O Nito (refere-se a Benito de Oliveira) quando ele morava sempre tinha opy. Eu ficava lá no Morro Sabiá também. Era amigo do padre, que gostava de prosear. Mas lá (em Arroio do Conde) juruá era bom, era amigo, mas não dava pra ficar. Não deixava viver como guarani antigo. Queria que guarani trabalhava na lavoura. E num é assim. Tem o sistema nosso, não é o mesmo sistema do juruá. E assim muitos vai se desgostando, vai indo, vai caminhando... Não gosta de briga. Nhanderu (nosso pai) não ensinou briga pro Guarani (Aldeia da Guarita/RS, em março de 2010).

Sebastião também contou sobre a desocupação de Arroio do Conde, na década de 1970:

(...) guaranizada foi saindo, foi entristecendo com juruá. Eu fui o último a sair, a ir pro Cantagalo. E assim foi. Depois não dava mais pra Guarani morar. Bichinho não tinha, água não tinha. Tudo foi ficando triste junto. Agora quando Guarani voltou não deixou. Polícia não deixou. É assim. Se dá briga, Guarani fica doente. Vai embora (Arroio do Conde, março de 2010).

Alguns deslocamentos, como podemos notar, acontecem por motivações contingenciais, resultantes de violência física e simbólica, sofrida no cotidiano, na subordinação às ordens, na necessidade de recebimento de alimentos para fins de sobrevivência, sendo a beligerância não acentuada em demasia ou não culminante em violência física por conta da negativa mbyá, que sabiamente a refuta de antemão.

Em documentos elaborados por agências estatais, a categoria acampamento é amplamente utilizada quando trata-se de ocupação em beira de estrada. A presença mbyá acontece em várias rodovias estaduais e federais do Brasil, como na BR-116 e BR-101, e também na RS-040, que liga a capital do estado do Rio Grande do Sul, Porto Alegre, ao litoral. Tais "acampamentos" situam-se em locais onde em tempos anteriores havia ocupações guarani, como podemos notar nos mapas 
históricos e registros arqueológicos. Garlet (1997, p. 95) observa que os acampamentos são consequência de esbulho territorial ocorrido nos primeiros séculos de colonização europeia: "Se forem tomados como base os antigos teko'a, ver-se-á que os atuais acampamentos estão disseminados à sua volta".

O que podemos perceber em Arasaty e em Nhüu Poty é que a memória mbyá acerca de ocupações anteriores, nas quais foram realizadas práticas xamânicas como a construção de opy (casa de reza) e a nominação de crianças, significa esses espaços enquanto teko'a, diferenciando-os de outros circundantes. Ocupações sazonais e acampamentos prescindem de significados xamânicos relevantes, sendo um teko'a configurado a partir de um processo de ocupação tradicional, o que implica em tempo, modo de uso e atividades investidas no intuito de acolher coletivos de parentes.

As ocupações sazonais, nos dias atuais, ocorrem para fins de venda de artesanato quando associada à estação quente do ano, tendo em vista a movimentação de pessoas em férias que impulsiona o aumento da circulação de veículos nas rodovias. Também no período de ara ymã (tempo velho, correspondente ao período de outono e inverno), após a colheita do avati (milho), é comum o deslocamento de famílias nucleares para locais de comercialização do artesanato, próximo de locais de caça, pesca e coleta. Ocupações não decorrentes da sazonalidade, como a grande maioria dos chamados "acampamentos", derivam da impossibilidade de acesso aos territórios tradicionais, e cumprem função paliativa. Nesse sentido, nem todos os acampamentos são reivindicados enquanto teko'a, mas certamente que os reivindicados atendem às condições para o exercício pleno do tekó (modo de ser/estar no mundo segundo os Mbyá) por contarem com orientações xamânicas e terem sido indicados por Nhanderu, conforme podemos observar na fala de Santiago Franco:

Qualquer lugar que ele escolhe, ele já sabe. Sabe que é lugar tipo assim, como juruá sempre fala: é um lugar sagrado. Que é um lugar bom pra guarani porque tudo antigamente que moraram lá ele sabe que é um lugar bem escolhido pelo Deus mesmo. E ai foi indicado pros mais velhos, pro karaí o lugar que vai ser pro guarani. Então isso significa pra nós que o lugar já é o lugar do 
guarani. Ali tem proteção do próprio Nhanderu... que vai ter a criança que também vai ser bom pra ela. Vai ser lugar pro guarani mesmo. Então a gente conhece isso porque é através do nosso Deus, já foi indicado isso pra lugar pra guarani (...). Fortalecendo a cultura... tudo tem significado... o lugar e sempre o Guarani fala que tem um teko'a. O tekó significa cultura, tradição, agricultura, fazendo dança, significa teko, teko'a que é o que a gente sempre mantém é a nossa cultura (Aldeia de Coxilha da Cruz/RS, março de 2010).

O antigo teko'a, então nominado como teko'a Pyau 8 , em Arroio do Conde, situava-se em local hoje cercado por propriedade juruá e data do mesmo período das ocupações mbyá na Pacheca (Camaquã/RS), Cantagalo (Viamão/RS) e Itapuã (Viamão/RS). Pode-se observar na narrativa de Francisco Timóteo, conforme dissertação de mestrado de Gonçalves (2011), que Cantagalo e Pacheca contaram com a anuência de autoridades juruá para serem ocupadas, enquanto que ocupações mbyá em Itapuã e Arroio do Conde não contaram com o mesmo posicionamento por motivos diversos:

Aí depois, quando eu fui lá pro Pacheca, cheguei lá... e vai fazer a casinha... roçar um tanto de mato... aí depois de quinze dias bem certinho morando lá em Pacheca entram lá quinze policiais armados. 'Com licença, quem é que é cacique aí?'. 'Cacique não tem... eu não sou cacique. Só quero atender as crianças, a gente daqui né?'. Aí ele falou com o sargento. 'Quem mandou vocês entrarem pelo mato aí? Quem mandou fazer roça aqui? Da onde vocês vieram?'. 'Eu vim lá da Argentina. Nasci lá pra Mangueirinha, no Paraná. Aí depois eu atravessei lá pro Kunha Piru, San Ignácio, aonde tem ruína. Aí depois (...) nós fomos lá pro Cerro Klano e, de lá, cheguei lá pro Cantagalo. Aí depois nós viemos aqui pro Pacheca'. 'Então tá bom. Vamos'. Aí me levaram lá pra Porto Alegre e chegamos lá no prefeito. 'Porque você está correndo por aí? Primeiro então você tirou licença lá pro Cantagalo, aí depois você foi lá pro Cantagalo... e depois você me vai lá pra

\footnotetext{
${ }^{8}$ Assim como uma pessoa mbyá pode ser nominada mais de uma vez no curso de sua vida, o mesmo pode ocorrer com um teko'a. Segundo os Mbyá, o nome advém das divindades e está diretamente relacionado à nhë'e (alma de origem divina), sendo necessário trocá-lo em função de doença e/ou por conduta moral, na tentativa de mudar o estado da pessoa. No caso, a situação pouco favorável da ocupação do teko 'a Pyau nas décadas de 1960 e 1970, bem como a impossibilidade de ser ocupada nas décadas seguintes motivou, desde o ponto de vista xamânico, uma nova nominação.
} 
Pacheca! O que você anda fazendo por aí?'. 'Nada. Eu não to correndo não. Cantagalo é meu. Pacheca é meu também, não é de vocês. Lá pra Pacheca tem nhambu, tem taquaruçu, tem peixe, tem tatu, tem quati, tem mel de abelha... aquilo é meu, não é seu. É pra mim sobreviver. Pacheca é nossa, é minha língua. E Nhambré também é minha língua, não é sua. Isso é meu. Como é que vocês pensam isso? E aí? Antes de vocês descobrirem isso aqui, vocês descobriram com o índio Guarani. Antigamente foi o índio que descobriu. (...) Por isso nós viemos pra cá'. 'Tá bom, tá bom, então tá bom'. 'Daqui nós vamos pra onde vocês dêem carta branca. O guarani tem carta branca'. 'Tá bom, é verdade mesmo isso que você falou. Pode ir trabalhando, pode ir seguindo... pra onde vocês quiserem morar então podem ir morar. Santa Catarina e Paraná, em qualquer ponto. Tem carta branca'. Aí depois, lá em Pacheca eu trabalhei oito anos como cacique (TIMÓTEO apud GONÇALVES, 2011, p. 54).

Em Itapuã há registros em jornais da época e narrativas mbyá sobre sua desocupação compulsória, e em Arroio do Conde encontramos o registro em jornal da presença da família de Francisco Kirimico Timóteo em local próximo ao indicado pelos Mbyá como sendo um antigo teko'a. As narrativas de Sebastião e Feliciano também evidenciam a relação assimétrica entre ameríndios e juruá no acesso ao território do entorno do Arroio. A desocupação mbyá desse teko'a não conta com relatos de afronta direta ou de violência física, por terem os Guarani silenciosamente resistido à tentativa de subordinação aos fazendeiros locais ${ }^{9}$.

O teko'a Arasaty está ocupado por um mesmo grupo de parentes há, no mínimo, cinquenta anos. Juancito Oliveira, sua primeira esposa Alicia e seus filhos, bem como Benito Oliveira, sua esposa Etelvina da Silva Gonçalves e seus filhos, entre eles Kondó (João Oliveira), viveram em Arasaty na década de 1960 e 1970. Em relação à década de 1980, são muitos os nomes mbyá presentes nas narrativas. Kondó e José de

\footnotetext{
${ }^{9}$ Nos últimos anos, pode-se observar algumas transformações no modo dos Guarani relacionarem-se com os juruá. Se até recentemente evitavam qualquer tipo de aproximação, atualmente têm buscado a regularização fundiária de seus territórios empenhando-se em organizar reuniões sobre temas relacionados à saúde e educação. Após a promulgação da Constituição de 1988 e com o apoio de pesquisadores e ONG's, como Anaí e PMG (Projeto Mbyá-Guarani), no RS, e CTI (Centro de Trabalho Indigenista), em SP, iniciaram movimentação no sentido de visibilizarem-se e ocuparem espaços juridicamente legítimos, contando com a atuação do Ministério Público Federal, que assumiu significativa importância nesse processo.
} 
Souza lembram de Feliciano (1984; atualmente vivendo na aldeia da Guarita e que também esteve em Arroio do Conde), Etelvina Fontoura (1986; atualmente vivendo em Cambirela-SC), Arthur Benitez (1985; atualmente vivendo na aldeia de Major Gercínio-SC), Núncio Benitez (1989; atualmente vivendo na aldeia de Coxilha da Cruz-RS), Silvano (1994; atualmente na aldeia de Coxilha da Cruz-RS) e Carlito Guaçu (1985; atualmente vivendo em Biguaçu/SC) ${ }^{10}$.

Arthur Benitez, que viveu no Petim entre os anos de 1985 e 1986, lembra que uma de suas filhas, Jurema, está enterrada nas proximidades da ponte sobre o arroio. Casada à época com Cambito, filho de Núncio Benitez, Jurema faleceu em decorrência de complicações no parto, juntamente com a criança recém-nascida. As mortes repentinas e/ou trágicas costumam desencadear a desocupação do teko'a. A alma guarani recebeu muita atenção de autores como Clastres (1978) e Nimuendaju (1987), os quais observaram sua ambivalência. Angué, de origem telúrica, terrena e nhë'e, de origem divina, constituem a pessoa mbyá e muitas são as prescrições e restrições alimentares, sexuais e de conduta para que angué não sobreponha-se à nhë'e, o que possibilitaria tomar a perspectiva de um outro ser (djepotá). A morte de Jurema desencadeou um breve afastamento de Arasaty, sendo novamente ocupada por outro coletivo de parentes mbyá meses depois.

Moradores do entorno do teko'a Arasaty, principalmente os funcionários aposentados do DNER (Departamento Nacional de Estradas e Rodagem), que vivem a aproximados $1 \mathrm{~km}$ do teko'a, contam que entre a ponte sobre o arroio Petim e a "lomba grande antes da chegada de Tapes" (trata-se, possivelmente, da localidade de Raia Pires), vivem famílias guarani desde a década de 1970.

A presença mbyá na região do arroio Passo Grande, assim como no Petim, também é de longa data. Os atuais moradores não índigenas da região do arroio Capivara (nome dado ao arroio Passo Grande a oeste do teko'a Nhüu Poty) afirmam a presença guarani desde, no mínimo, a metade do século XX. Ao que tudo indica, a partir das narrativas de dois moradores entrevistados ${ }^{1}$, houve ocupações mbyá nas proximidades do

\footnotetext{
${ }^{10}$ Com exceção de Carlito Guaçu e Etelvina Fontoura, todos os demais foram entrevistados.

${ }^{11}$ Optamos por não citar o nome e sobrenome dos moradores não indígenas entrevistados durante os trabalhos de campo, tendo em vista que trata-se de áreas em estudo para identificação e demarcação de Terras Indígenas pela Fundação Nacional do Índio (FUNAI).
} 
lugar ao longo das décadas de 1960, 1970 e 1980. Apontam o local onde atualmente localiza-se a Cabanha Feltrin como sendo referência para uma das ocupações, recordando-se de "brincar com os índios". Um deles, proprietário de uma pequena área na região, lembra-se que pescavam na beira do arroio e que confeccionavam balaios, vendidos para os juruá do entorno ou trocados por alimentos. O outro morador, nascido na década de 1940, contou que alguns Guarani trabalhavam nas plantações de seus vizinhos e que viviam em espaço bastante restrito, sem poder cultivar milho, mandioca e demais alimentos para consumo próprio. Afirmou que durante dois ou três anos uma família guarani viveu em terras que estavam sob titularidade de seu tio. Assim como o primeiro morador citado, lembra-se de brincar com as crianças guarani e também de tentar aprender o trançado dos balaios. Contou ainda que seus parentes não deixavam os indígenas plantarem para si, motivo pelo qual acredita que tenham se afastado do local e permanecido nas beiras de estrada da região. Ambos contaram que os indígenas viviam em aproximadamente quatro casas, feitas de capim, taquara e folha de coqueiro (pindó).

Em relação às narrativas guarani acerca de ocupações anteriores à atual em Passo Grande, o casal Bonifácio Morinico e Felicita Fernandez (que hoje está na aldeia de Água Grande/RS e também é lembrada como Alicia12) é referido como tendo vivido nos arredores da ponte sobre o arroio, na década de 1970. Na década de 1980 a presença da família de Perumi, que viveu junto com sua esposa Catarina e filhos nos anos de 1984 e 198513, é relembrada. Segundo os Mbyá, uma das filhas de Perumi, ainda criança, faleceu em Nhüu Poty e foi enterrada em cemintério no teko'a Jatai'ty (aldeia do Cantagalo/Viamão-RS), tendo em vista que os brancos não permitiram sepultá-la no local onde faleceu.

Durante nossos trabalhos de campo, realizados nos anos de 2009 e 2010, encontravam-se cerca de oitenta e nove pessoas no teko'a Nhuu Poty, pertencentes a dois kuéry ${ }^{14}$, que tinham como lideranças

\footnotetext{
${ }^{12}$ Os nomes não indígenas são muitas vezes trocados ao longo da vida mbyá, principalmente os referentes a pessoas de mais idade. Os nomes mbyá também podem ser trocados, mas em decorrência de recomendação do karaí (xamã) e não aleatoriamente (gostos, escolhas pessoais), como costuma acontecer com nominação não indígena.

${ }^{13}$ Perumi é falecido e Catarina e filhos vivem no teko'a Ka'aguy Porã (Estrela Velha/RS).

${ }^{14}$ Termo que designa coletivo, no sentido de "pessoal", "turma", tal como costumam mencionar os Mbyá. (ASSIS, 2006).
} 
CÉSAR CASTRO PEREIRA e MARIA PAULA PRATES - Nas margens da estrada...

políticas $^{15}$ André Fernandez e Mariano Garay. Diferentemente de Arasaty, com aproximadamente vinte e cinco pessoas e onde encontramos apenas um núcleo de moradias, existiam três em Nhüu Poty. No sentido norte - sul, do lado esquerdo da BR 116, o primeiro local ( $k$ 315,5), ocupado pela família de Mariano Fernandez (pai de André Fernandez). Seis moradias, duas feitas de barro e as demais de taquara, onde viviam cerca de vinte e cinco pessoas. Dois quilômetros a

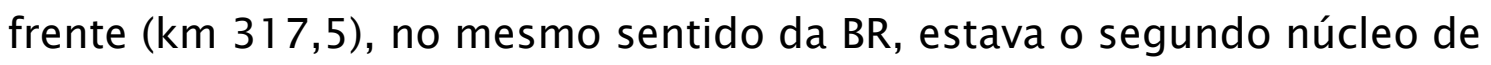
moradias, onde viviam Mariano Garay e parentes, rede extensa constituída por aproximadamente sessenta e quatro pessoas. Já na margem direita do sentido norte - sul, ainda pela BR 116 (km 318,5), logo após a ponte sobre o arroio Passo Grande, localizava-se outro núcleo de moradias, desta vez associado à rede de Mariano Garay, diferentemente do primeiro, o qual apresentava independência nas atividades produtivas e também autonomia nas decisões internas. Rosalina Fernandez, irmã de Mariano Garay, viveu no local juntamente com suas duas filhas, um genro e netos, até os últimos dias de 2010, quando as moradias foram subitamente incendiadas. As causas continuam desconhecidas e há procedimentos instaurados na Polícia Federal e no Ministério Público Federal para fins de investigação.

Em Arroio do Conde, as circunstâncias que envolveram as ocupações distinguem-se das envolvidas nesses dois teko'a. As alianças com moradores brancos do entorno não foram possíveis devido a uma maior hostilidade por parte destes e, além do mais, a intensa urbanização da região nos últimos trinta anos acelerou o desmatamento ciliar, afugentando animais e poluindo a água do arroio. Enquanto no Petim e Passo Grande predominam pequenas propriedades rurais, restando relativa mata nativa nas bordas dos arroios e no cume dos morros, Arroio do Conde está cercada por vilas, plantações de arroz e indústrias, assentadas nos últimos anos. A última ocupação do teko'a Takuaty ocorreu no ano de 2008, quando Santiago Franco e sua família construíram moradias próximas à ponte que estabelece o limite entre os municípios de Eldorado do Sul e Guaíba. Foram retirados após cumprimento de ação impetrada pela Fundação Estadual de Pesquisa

\footnotetext{
${ }^{15}$ Refirimo-nos à liderança política no sentido de interlocutor, de mediador em reuniões e discussões com os juruá.
} 
Agropecuária (FEPAGRO), que reivindicou a posse da terra. Os Guarani ocupavam as margens da estrada do Conde (rodovia estadual), e, mesmo assim, a juíza de instância estadual, nominando-os erroneamente de Kaingang, concedeu a liminar. Ademais de retirados do local, o manejo da área é realizado regularmente pelos indígenas, que coletam taquara para confecção de balaios e também ervas medicinais.

Os dados sobre as ocupações mbyá no Petim e Passo Grande, sejam narrativas de brancos moradores do entorno, de memória oral dos tujá (anciãos) e até mesmo de fotografias tiradas em décadas passadas, indicam que a presença nos teko'a se dá de modo permanente nas últimas décadas. Em relação à ocupação mbyá em Arroio do Conde, os dados arqueológicos são riquíssimos e apontam a existência de significativa presença guarani em tempo pretérito (LEITE, 1975; NOELLI, 1993). No presente estão impossibilitados de construir moradias no local.

Estudos históricos indicam que os Mbyá contemporâneos descendem dos "índios monteses", assim denominados no período colonial. $O$ adjetivo advém de Montes (em espanhol), do local de mata onde esconderam-se dos invasores juruá. Depois, em estudos como os do paraguaio Cadogan (1997) e nos escritos sobre as viagens às Missões argentinas de Ambrosetti (1895), foram associados aos "Cainguá", denominação provavelmente advinda de Ka'agüy (mata, floresta em mbyá), que habitavam o Paraguai no século XIX. Os mapas elaborados a partir de estudos arqueológicos, conforme observa-se a seguir, indicam a presença guarani na região dos atuais teko'a Takuaty Porã, Arasaty e Nhüu Poty há pelo menos mil anos. Oriundos da Amazônia, grupos guarani teriam chegado à região da bacia platina através de seus afluentes Paraguai, Paraná, Uruguai há aproximados dois mil anos, adentrando na região do rio Jacuí, que atravessa o atual 
estado do Rio Grande do Sul16. Ocuparam as margens dos rios, ricos pela cobertura da mata atlântica, tal como em prática na ocupação territorial atual. O mapa etno-histórico de Curt Nimuendaju aponta a presença guarani na região no século XX.

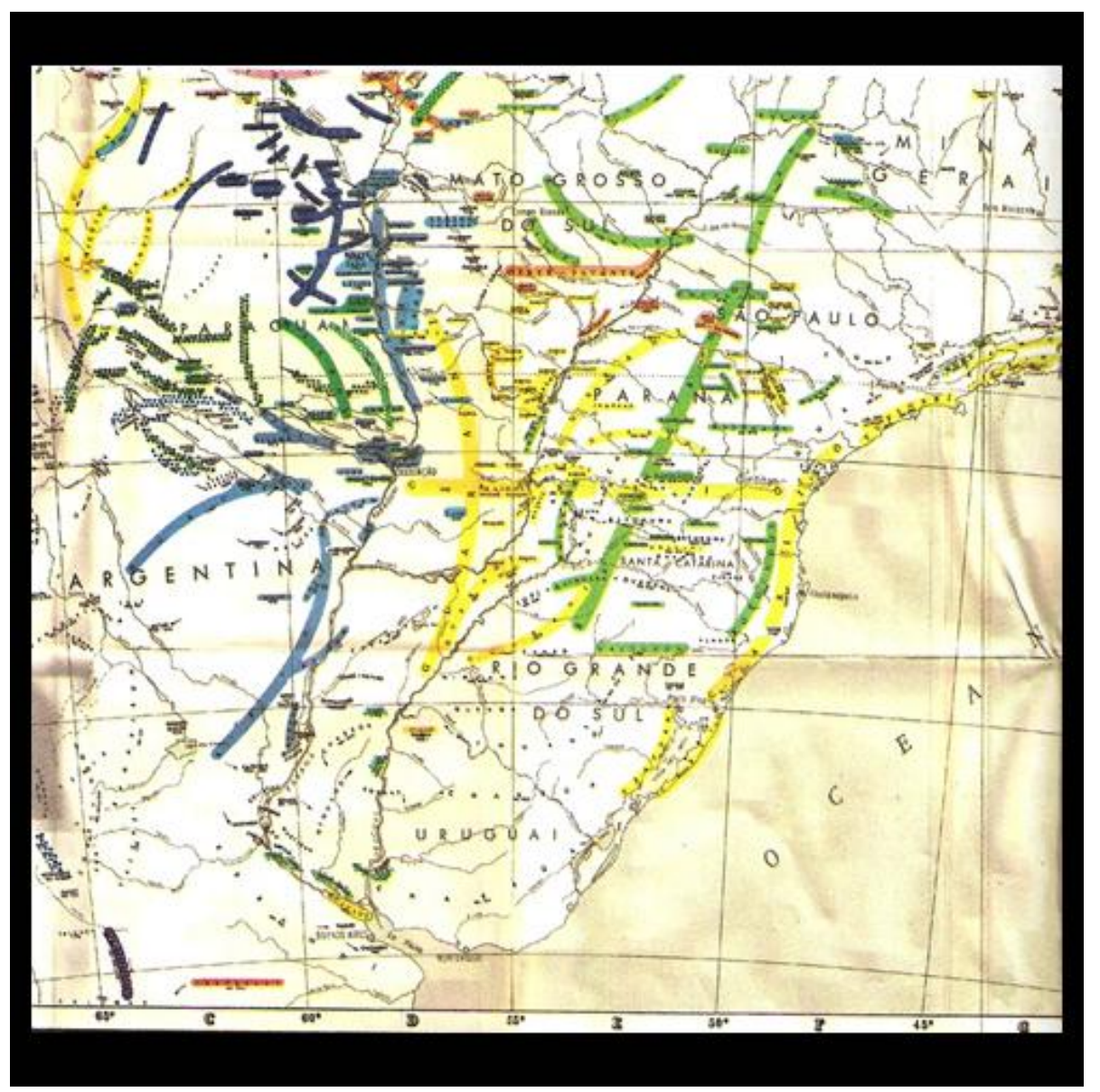

IMAGEM 01. Mapa Etno-histórico de Curt Nimuendaju, de 1944. Em amarelo, a localização de indígenas falantes de línguas do tronco Tupi-Guarani. Note-se a localização de tais grupos na borda do Lago Guaiba e da Laguna dos Patos (NIMUENDAJU, 1981).

De um modo geral, são escassos os estudos de história indígena ou que, pelo menos, contemplem a participação nativa na construção territorial, política, econômica e cultural do estado do Rio Grande do Sul. A situação torna-se mais crítica principalmente a partir da segunda metade do século XVIII. Devido à derrota sofrida pelos Guarani missioneiros na guerra de 1754-56 e por causa da expulsão dos 
jesuítas dos territórios espanhóis em 176817, as informações por registro escrito sobre a presença indígena tornaram-se esparsas. Embora espanhóis e portugueses entrassem em contato com mais frequência com indígenas missioneiros ou com os chamados 'infiéis' e, por conta disso, os registros escritos referentes ao período das missões sejam mais abundantes, a presença nativa na região em foco também foi registrada durante os períodos colonial, imperial e republicano.

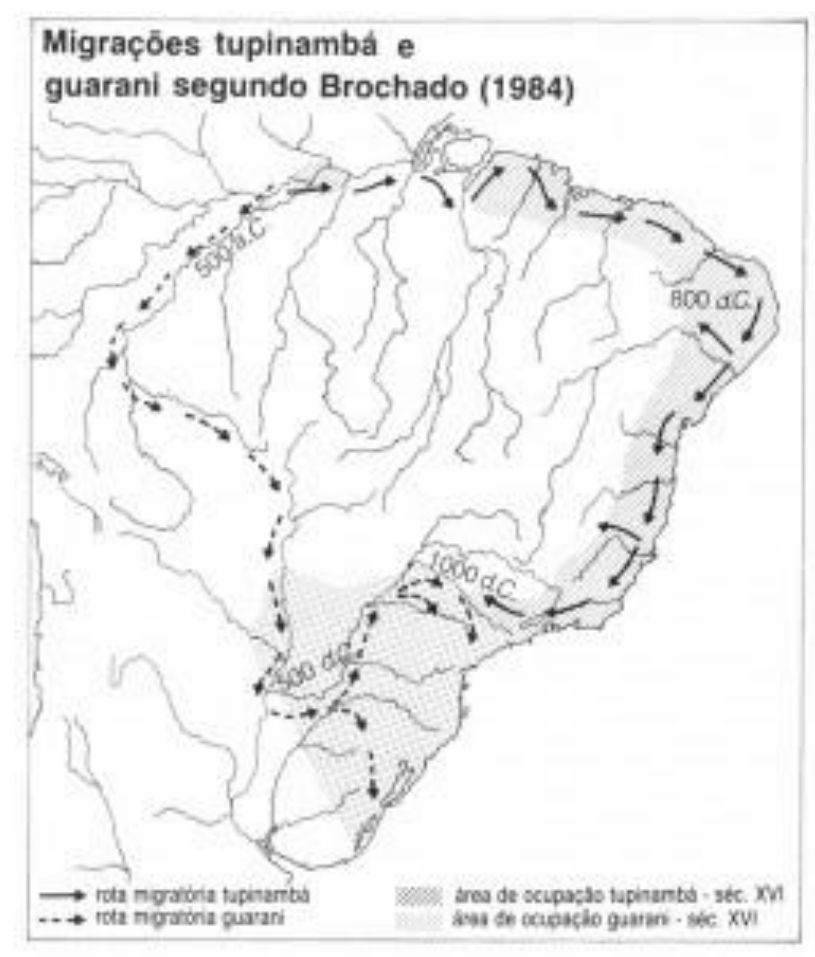

IMAGEM 02. Mapa sobre as rotas migratórias tupinambá e guarani nos séculos XVI e XVII. Note-se a indicação da seta para região oeste da Lagoa dos Patos (BROCHADO, 1984).

Os primeiros registros escritos pesquisados provêm de mapas de viajantes/exploradores. Uma das principais características dos primeiros mapas europeus na América, comparando com os mapas produzidos a partir do final do século XVIII, é o fato de registrarem as populações indígenas da região a partir de seus etnônimos. Os europeus tinham a preocupação em nomear os nativos, em identificá-los a fim de

\footnotetext{
${ }^{17}$ Em se tratando de historiografia gaúcha, durante muitas décadas somente dois autores dedicaram apenas um capítulo para o período posterior aos jesuítas. Estes foram: Aurélio Porto (1943) e Carlos Teschauer (1922).
} 
estabelecer acordos e alianças para obter o sucesso da colonização 18 . Conforme os mapas abaixo, é possível observar a presença nativa em diversas regiões da bacia platina, entre elas a de indígenas Guarani na costa oeste da Lagoa dos Patos.

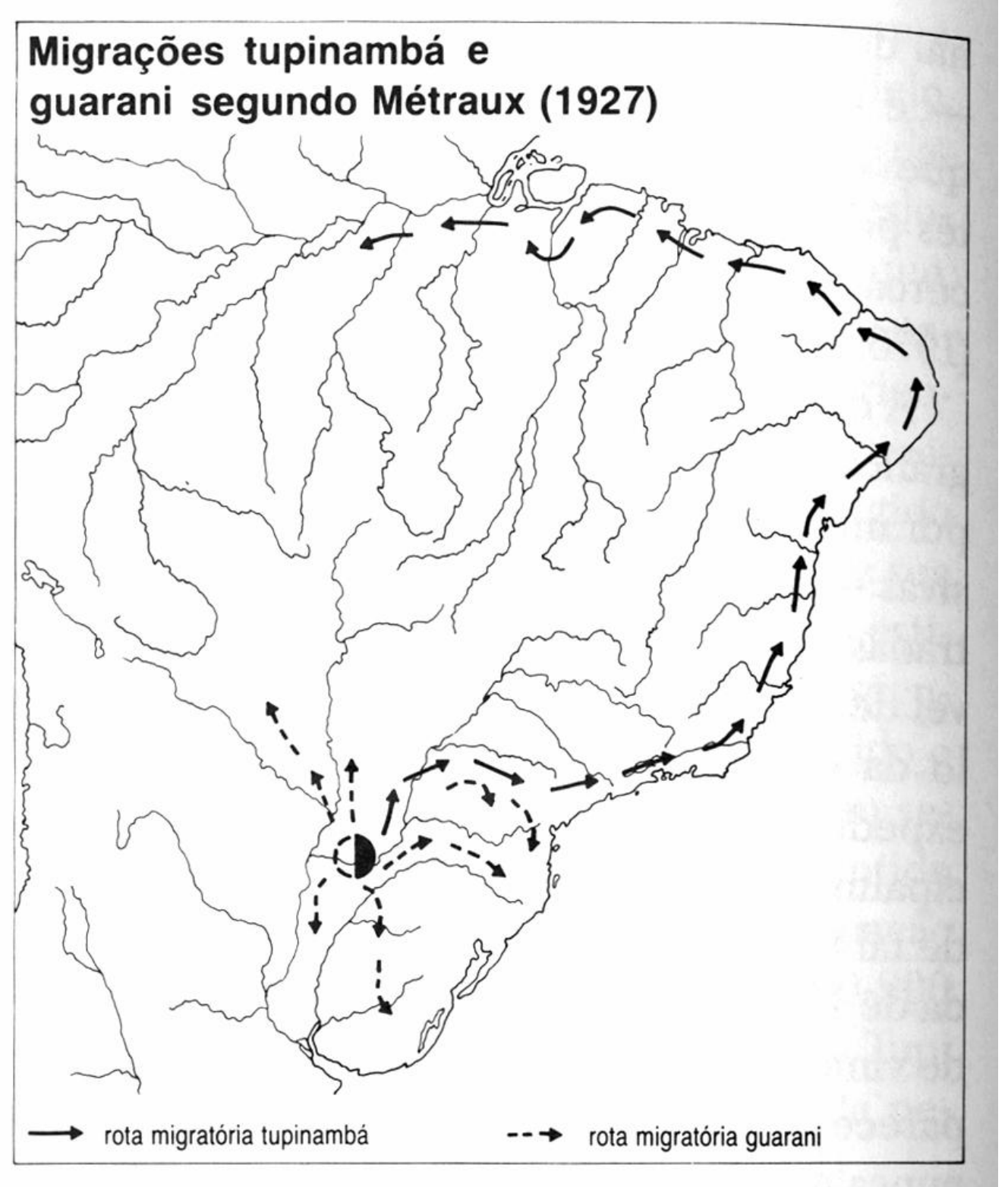

IMAGEM 03. Mapa sobre as rotas migratórias tupinambá e guarani (METRAUX, 1927).

\footnotetext{
${ }^{18}$ Identificar possíveis aliados era uma estratégia europeia para o sucesso da empresa colonizadora não só na América. Nas palavras de Russel-Wood (1998, p. 16), o Império lusitano foi construído "com e não isoladamente contra os povos com os quais entraram em contato".
} 


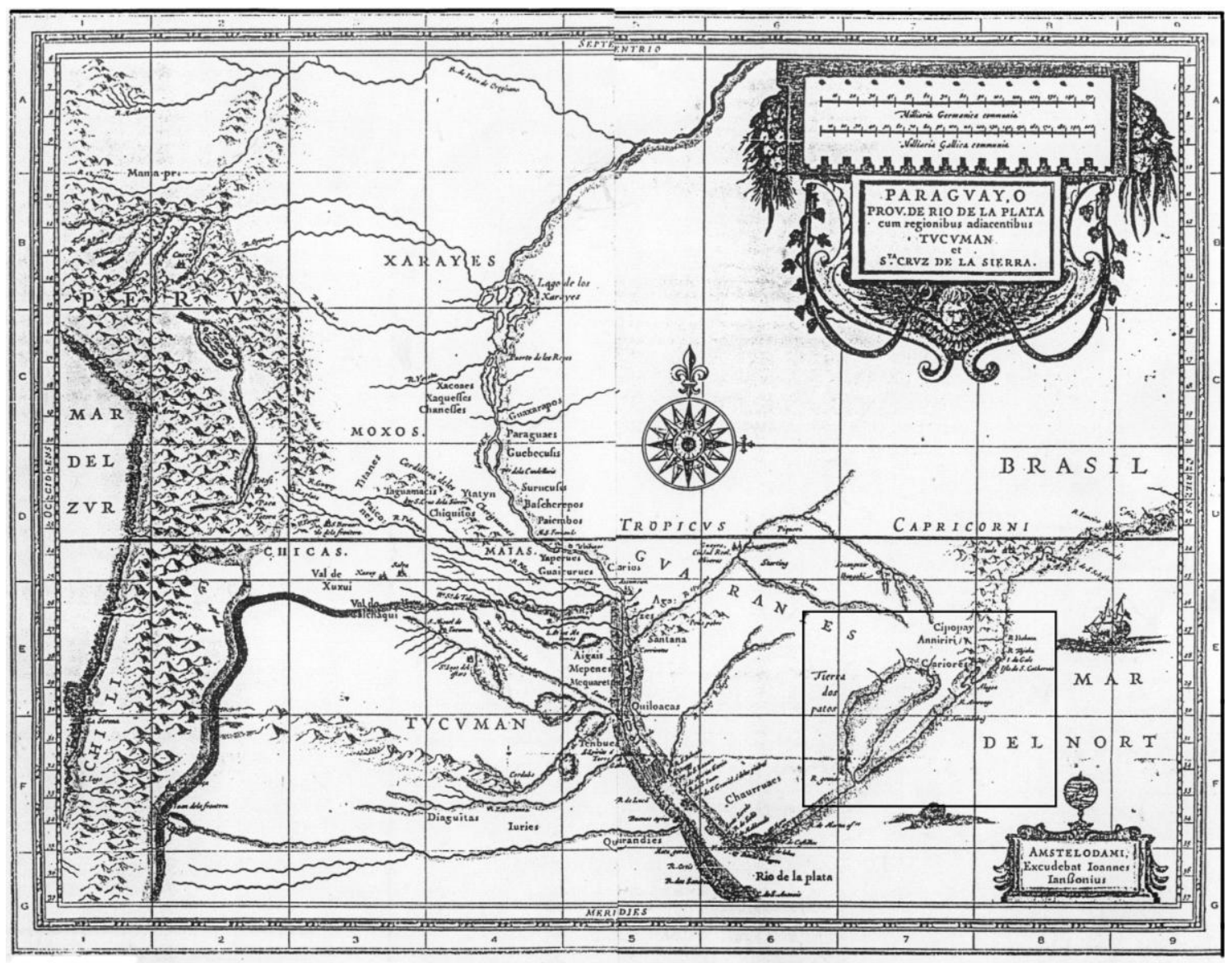

IMAGEM 04. Mapa do Paraguay ó Provincia de Rio de la Plata cum regionibus adiacentibus Tucuman et Sta. Cruz de la Sierra, 1630. FURLONG, G. Cartografia Jesuítica del Río de la Plata. Buenos Aires, Facultad de Filosofia y Letras 1936, op. cit., Lâmina I, n. 06 do Catálogo, p.26 do texto. BARCELlOS, A. O Compasso e a Cruz. Cartografia Jesuítica da América Colonial. (CD-ROM, 2006).

Além dos viajantes/exploradores, cronistas registraram a população nativa da região. Ruy Diaz de Guzmán foi o primeiro a mencionar os indígenas da Laguna dos Patos, em 1612, em escrito chamado La Argentina. Guzmán (1612) registra o cenário no interior do território, nas margens da Lagoa dos Patos a partir de Rio Grande, localizada bem na embocadura com o oceano Atlântico, indicando a presença de milhares de indígenas Guarani. Descrição de Guzmán:

La primera parte de esta costa, que contiene con el Rio de la Plata, es llana y desabrigada hasta la isla de Santa Catalina, con dos o tres puertos para navios pequeños; el primer es junto a los Castillos; el segundo es el Rio Grande que dista 60 leguas del de la Plata; éste tiene dificultad en la entrada por la gran corriente 
con que sale al mar, frontero de una isla pequeña que le encubre la boca, y entrando dentro, es seguro y anchuroso, y se extiende como lago a cuyas riberas de una y otra parte están poblados más de 20.000 indios guaraníes, que los que de aquella tierra llaman Arechanes, no porque en las constumbres y lenguajes se diferenciasen de los demás de esta nación, sino porque traen el cabello revuelto y encrespado para arriba. Es gente muy dispuesta y corpulenta, y ordinariamente tienen guerra con los indios Charrua del Río de la Plata, y con otros de tierra adentro(...) (GUZMÁN, 1612, n./p.).

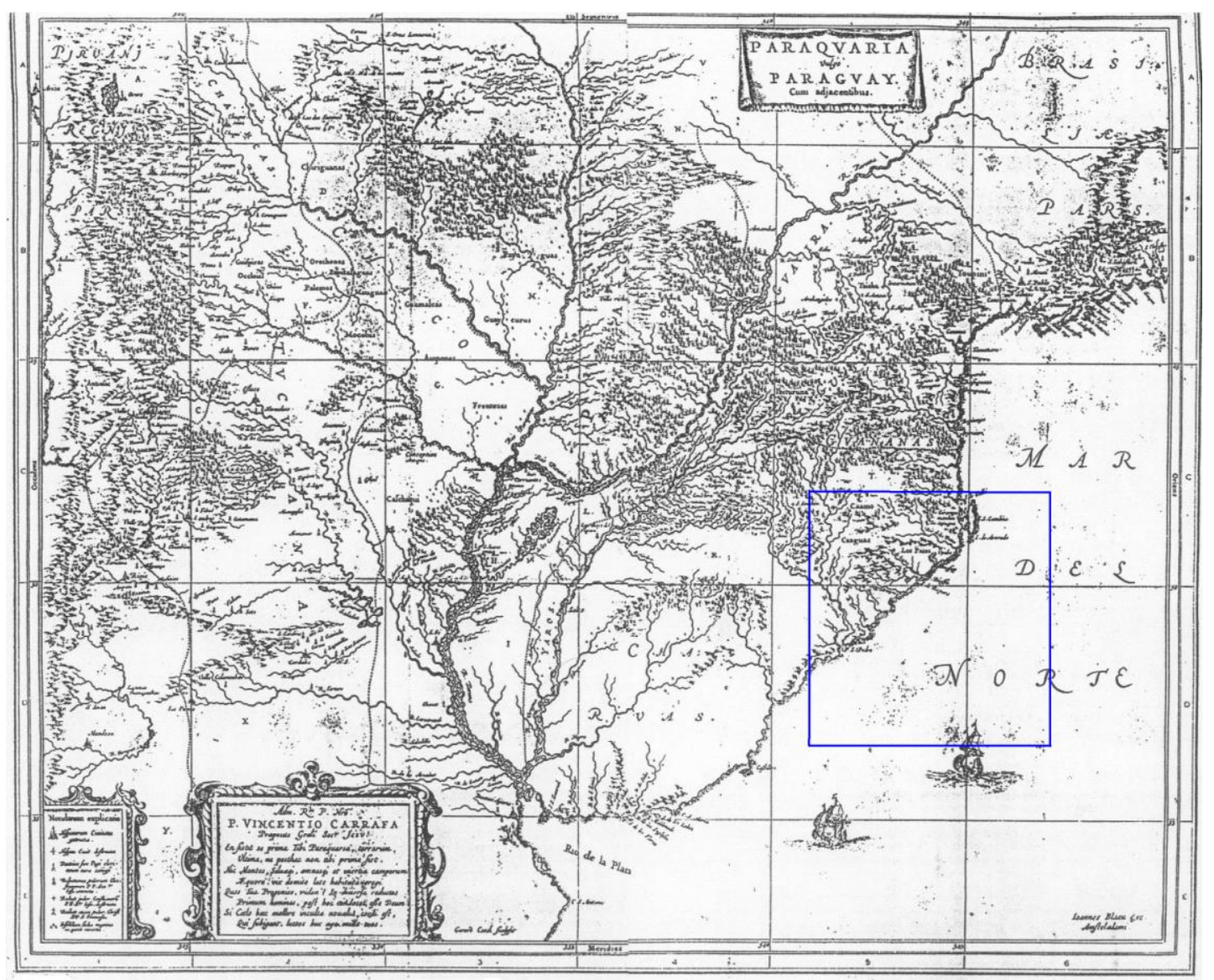

IMAGEM 05. Mapa Paraquaria Vulgo Paraguay cum adjacentibus. P. Luis Ernot, 1632. John Ogilby in: MONTANUS, A. America: being the latest and most accurate description of the New World. London 1671. Furlong, 1936, op. cit., n. 03 do Catálogo, p.24 do texto. Não publicado em FURLONG. BARCELLOS, Arthur H. F. O Compasso e a Cruz. Cartografia Jesuítica da América Colonial. (CD-ROM, 2006). 


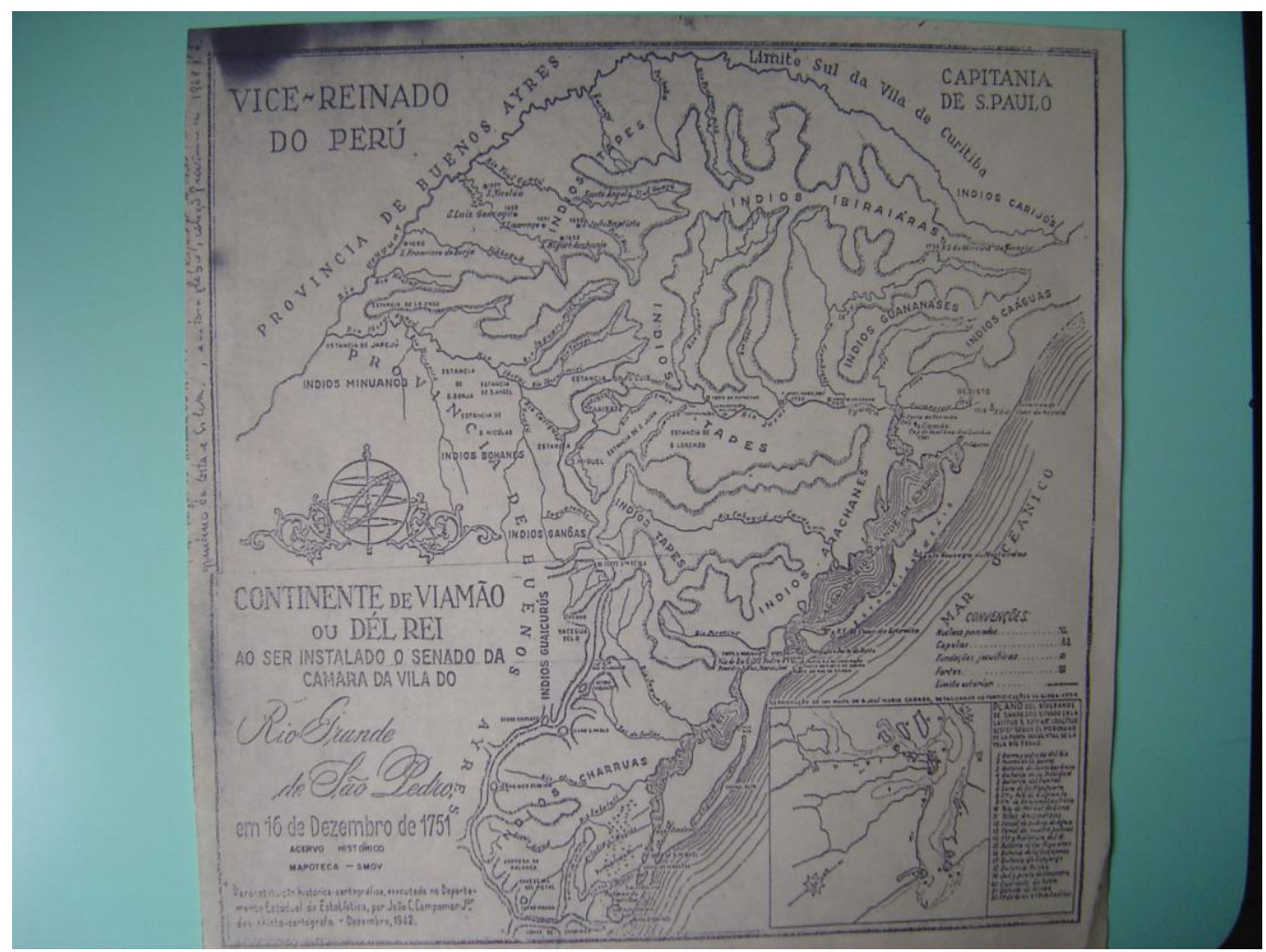

IMAGEM 06. Mapa do Vice-Reino do Peru. Fotografado no Arquivo Histórico do RS.

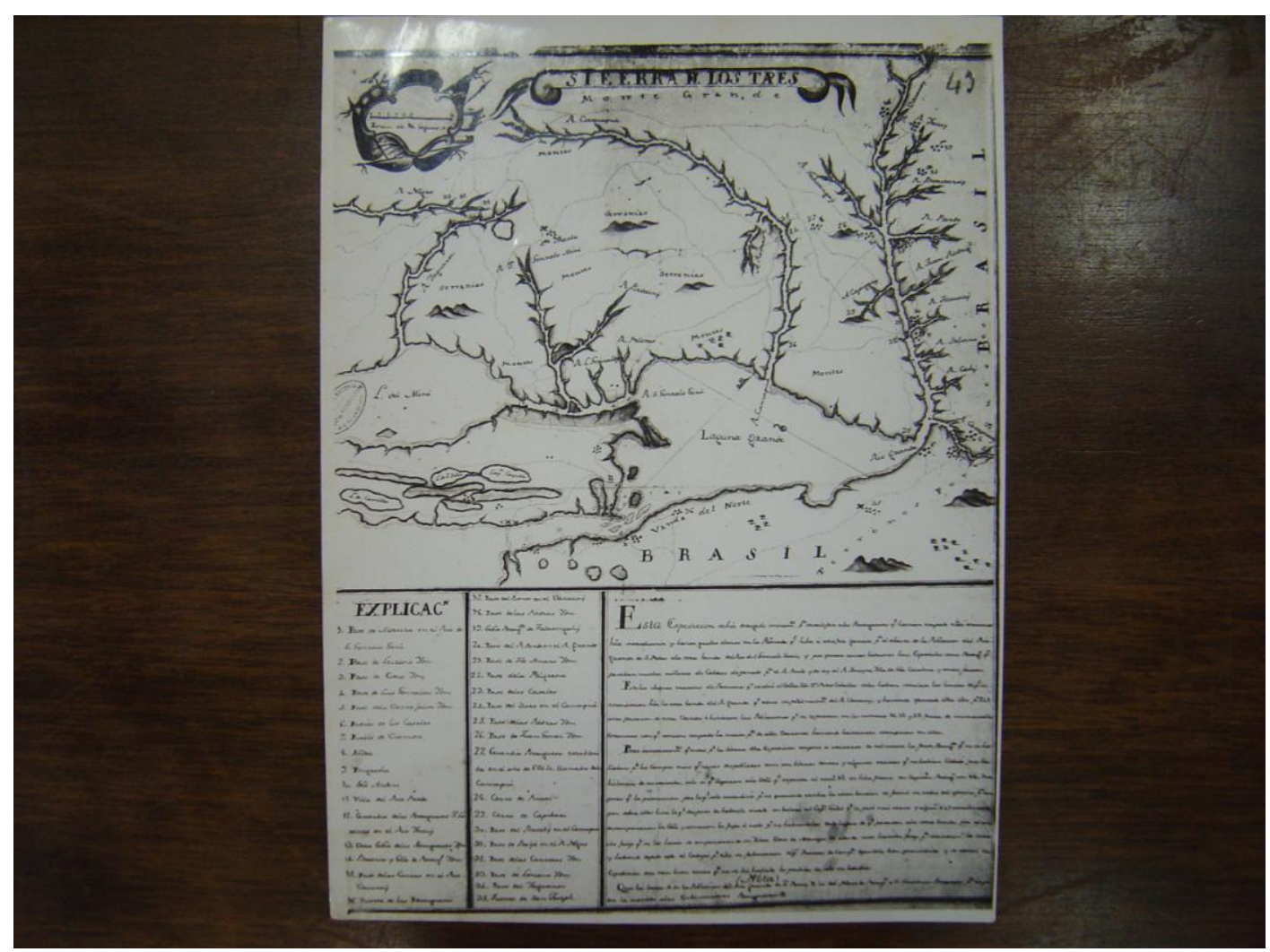

IMAGEM 07. Mapa Sierra Los Tapes. Foto de Bruno Marques. Arquivo Histórico do RS. 
Auguste Saint-Hilaire, botânico e pesquisador francês, por exemplo, registrou muitas observações sobre os Guarani enquanto passou por Porto Alegre, Missões e navegou pelo Jacuí e Rio da Prata, entre 1820 e 1821. No seu diário "Viagem ao Rio Grande do Sul" reparou que

Vários prisioneiros a quem interroguei disseram-me serem paraguaios, e que trabalhavam como peões na Província de Entre-Rios, tendo sido obrigados por Artigas a pegar em armas. É muito provável que esta gente esteja mentindo e que tenha acompanhado seu chefe na esperança de praticarem a pilhagem. Como quer que seja, os prisioneiros guaranis são, em geral, homens de baixa estatura, mas parecendo pequenos em razão do corpo apresentar desmesurada largura (...). Os guaranis são mais feios e mostram na fisionomia uma expressão de baixeza, devido talvez unicamente ao sentimento de sua inferioridade, à dependência em que vivem atualmente e ao estado de cativeiro que se encontram atualmente reduzidos. Mas examinados com atenção, percebe-se, entre os traços repugnantes que os caracterizam, um ar de docilidade, indicador de seu bom caráter (SAINT-HILAIRE, 1999, p. 48).

Continuando a sua descrição Saint-Hilaire:

Entre a campanha e o lugar onde parei, vimos às margens do rio, aldeias habitadas por índios guaranis vindos de Entre-Rios para se refugiar aqui. Suas casas não passam de choupanas frequentemente, a altura de um homem e construídas à semelhança de barracas de acampamento, com folhas e haste de uma gramínea dura e muito lisa. Ao lado das choupanas miseráveis há, geralmente, onde penduram nacos de carne; de vez em quando, vêem-se também na volta dessas cabanas, pés de milho, abóboras e melancias. Raramente se dão ao trabalho de roçar todo o terreno, onde semearam essas plantas que já mencionei, mas, em meio a um terreno baldio, abriram buracos um ao lado do outro, e ali lançaram grãos que não param de germinar pela intensa fertilidade do solo (SAINT-HILAIRE, 1999, p. 48-49). 
Ademais do tom preconceituoso do viajante, as informações acima convergem com o modo de vida observado em um teko'a nos dias de hoje. A seguir prossegue:

Se as mulheres guaranis se entregam aos homens com tanta facilidade, não é realmente tanto por libertinagem, se não em consequência desse espírito de servilismo que as impede de nada recusar. Aqui, a maior parte dos milicianos tem uma índia por companheira. Estas mulheres são úteis para eles, porque sabem lavar e costurar razoavelmente. Mas o que há de aborrecido é que os filhos nascidos dessas uniões transitórias são necessariamente abandonados pelo pai e maleducados, porque serão pelas índias e assim se parecerão com os gaúchos espanhóis pouco a pouco, a raça branca degenerar-se-á na Capitania do Rio Grande do Sul (SAINT-HILAIRE, 1999, p. 277).

Dos escritos de Saint-Hilaire, percebe-se que os indígenas não são apreendidos enquanto habitantes nativos que transitam livremente pelo seu território. Agora são escravos, são gente tratada como inferior e as poucas aldeias avistadas são descritas como precárias. A menção a Entre-Rios é bastante recorrente nos escritos desse autor e diz respeito a uma Província Argentina que ainda nos dias contemporâneos abriga aldeias guarani.

O século XVIII, principalmente após a Guerra Guaranítica, é marcado pela dispersão dos Guarani pela bacia platina. Há diversos registros, em especial de jesuítas, que dão conta da fuga dos Guarani para os montes ou para os toldos dos infiéis ${ }^{19}$. Também a passagem de cerca de três mil Guarani para os domínios portugueses contribuiu para o declínio populacional das missões jesuíticas. Habitando o território português, logo surgiram os primeiros conflitos. Apesar da legislação

\footnotetext{
19 " [...] lance de dejar sus casas, pueblos, sementeras y yerbales, en que tienen pegado el corazon, será huirse a los montes de su antigua infidelidad" (p. 134). Subsequencia do Tratado de 1750 - oposição dos Jesuítas Archivo General de Simancas - Legajo 7377, folio 24. Coleção Varnhagen, doc. 57 Carta do Padre José de Barreda ao confessor do Rei de Espanha. Buenos Aires, 28/04/1752 (pág. 134-136). In. Anais da Biblioteca Nacional. Vol LII, 1930. "[...] Y tambien han llegado al estremo hacer alianza y llamar en su ayuda a los Indios Barbaros, e Infieles que Charruas y Minuanes". Pág. 39. Madrid, abril de 1754 - De D. Francisco Auzmendi, Diretor Geral da Secretária de Estado dos Negócios Estrangeiros. Informação para o Ministro Ricardo Wall, inteirando-o do que havia ocorrido no tempo do seu antecessor (Carvajal), desde 1747 até o fim de Janeiro de 1754, sobre as antecedências e subsequências do Tratado de Limites de 1750. (p. 31-40).
} 
portuguesa incentivar a incorporação nativa aos 'brancos'20, a relação foi de difícil trato. Poucos anos após a chegada dos Guarani à região portuguesa, muitos já manifestavam seu desejo em voltar às reduções, o que era impedido com severidade pelos portugueses. Em uma investigação levada a cabo pelo governador de Buenos Aires sobre desertores espanhóis, várias testemunhas dão conta da situação peculiar em que se encontravam os indígenas em território lusitano. Disseram diversos militares que estiveram no Brasil que muitos deles tentavam retornar às missões, mas os portugueses haviam colocado guardas nos caminhos e os castigavam com muita violência. Roque Romero, um espanhol que havia vivido dez anos em Rio Grande, afirmou que "por todo el terreno que corre desde el Río Pardo hasta el Río Grande a visto muchos indios e indias de estes Pueblos [Missões Orientais do Uruguai]"21. Nesse mesmo inquérito, o Alferes Miguel Vidal fez uma estimativa dos indígenas que viu quando por lá passou: "en el Río Pardo habia más de 1.500 almas, fuera de 400 que están en Viamont $\mathrm{y}$ otras porciones que han enviado tierra adentro a varios parages"22. O soldado Joseph Sánchez foi testemunha ocular da prisão de um grupo de Guarani que tentava voltar às missões. De acordo com seu depoimento, foram castigados, levados para Rio Pardo "y después los despachan tierra adentro"23.

\footnotetext{
${ }^{20}$ O Decreto Real de 4 de abril de 1755 (conhecido como Diretório dos Índios) recomendava o casamento de portugueses com índias, não ficando tais vassalos "com infâmia alguma, se farão dignos da minha real atenção e serão preferidos nas terras".

${ }^{21}$ Depoimento de Roque Romero, espanhol que viveu 10 anos em Rio Grande, 14/11/1759. Información hecha por el Teniente Coronel y Mayor General del Ejército Don Diogo de Salas, de orden del Ex.mo Señor Don Pedro de Cevallos, Teniente General de los Reales Ejércitos, Governador y Capitán General de esta Província sobre la retención de los desertores españoles, sedución y extracción de Indios, robos y matanzas de ganado que han ejecutado los portugueses. Archivo General de Simanacas - Secretaria de Estado, Legajo 7405. Doc. $n^{\circ} 71$. p. 6R.

${ }^{22}$ Depoimento de Miguel Vidal, Alferes de Dragões do Presídio de Buenos Aires, 17/11/1759. Información hecha por el Teniente Coronel y Mayor General del Ejército Don Diogo de Salas, de orden del Ex.mo Señor Don Pedro de Cevallos, Teniente General de los Reales Ejércitos, Governador y Capitán General de esta Província sobre la retención de los desertores españoles, sedución y extracción de Indios, robos y matanzas de ganado que han ejecutado los portugueses. Archivo General de Simanacas Secretaria de Estado, Legajo 7405. Doc. $n^{\circ} 71$. p. 11V.

${ }^{23}$ Depoimento de Joseph Sánchez, soldado de Dragão do Corpo de Buenos Aires, 18/11/1759. Información hecha por el Teniente Coronel y Mayor General del Ejército Don Diogo de Salas, de orden del Ex.mo Señor Don Pedro de Cevallos, Teniente General de los Reales Ejércitos, Governador y Capitán General de esta Província sobre la retención de los desertores españoles, sedución y extracción de Indios, robos y matanzas de ganado que han ejecutado los portugueses. Archivo General de Simanacas Secretaria de Estado, Legajo 7405. Doc. $n^{\circ}$ 71. p.13R.
} 
O século XIX merece ser observado com mais atenção. Em seu transcurso a situação política da América colonial mudou radicalmente. Das colônias emergiram países independentes, porém muitos instáveis. Eram tempos incertos, o poder centralizador das novas nações chocavase contra o crescente poder da elite local, igualmente belicosa. No Rio Grande do Sul, o contexto foi caracterizado pela expansão populacional e ocupação de territórios recentemente conquistados e crescente instabilidade política. Diversas vilas, freguesias, distritos são criados. Em todo o Estado são estabelecidos postos de administração portuguesa (e mais tarde brasileira). À medida que aumenta a presença lusitana no território, cresce a ocorrência de registros de indígenas no território sulino. Diante da expansão da criação do gado e das estâncias, da legislação deficiente, do acelerado declínio da vida missional e da miscigenação, intensifica-se o processo de expropriação do território guarani e de marginalização das populações indígenas.

Comparando com outras regiões da América portuguesa, Portugal, tardiamente, investiu no povoamento do Brasil meridional. As primeiras tentativas de estabelecimento ao sul da América partem de comerciantes portugueses instalados em Buenos Aires logo após a fundação definitiva desta cidade, em 1580 (CANABRAVA, 1944). Depois de décadas atuando no comércio de Buenos Aires, muitos portugueses são expulsos por Decreto Real após o fim da União Ibérica24; anos mais tarde, em 1680, com financiamento de negociantes instalados na praça do Rio de Janeiro e com apoio logístico e material da metrópole, Portugal funda a cidade de Colônia de Sacramento na margem esquerda da foz do Rio da Prata, em frente a Buenos Aires (PRADO, 2002).

\footnotetext{
${ }^{24}$ O rei de Portugal Don Sebastião morreu em 1578 sem deixar descendentes diretos. Então, pelas políticas de casamento, Portugal uniu-se à Espanha formando a chamada União Ibérica (1580-1640). Durante os 60 anos da União Ibérica, o Tratado de Tordesilhas, firmado em 1494, em consequência da chegada de Cristovão Colombo ao Novo Mundo, estabelecendo a divisão do ainda desconhecido continente americano entre Portugal e Espanha, deixou de fazer sentido, possibilitando que espanhóis e portugueses pudessem circular livremente pelo território das duas coroas.
} 
A desembocadura do Rio da Prata assume, então, um ponto estratégico à época. Através do Rio da Prata, navegava-se pelo interior do continente sul-americano, possibilitando a aproximação com as minas de prata de Potosí, com a cidade de Lima, capital do Vice-Reino Peru (em 1776 o Vice-Reino divide-se em Vice-Reino do Peru, com capital em Lima, e em Vice-Reino do Rio da Prata, com capital em Buenos Aires), e com a próspera cidade de Assunção. Além disso, pelo Rio da Prata, escoavam toneladas de prata retiradas de Potosí. Portanto controlar a navegação do Rio da Prata significava reter uma grande quantidade do valioso metal.

Concomitante a esse processo, jesuítas a serviço da Espanha passaram a desenvolver aldeamentos de indígenas Guarani na chamada Província do Paraguai (atuais sul do Paraguai, nordeste da Argentina e noroeste do Rio Grande do Sul) e no Guairá (atual oeste dos estados do Paraná e Mato Grosso do Sul). No período do Vice-Reino do Peru, o atual território do Rio Grande do Sul era denominado Província do Tape, e as Reduções do século XVII estavam no centro do estado, ao longo dos rios Jacuí e Ibicuí. Já no período do Vice-Reino do Rio da Prata, as configurações espaciais sofrem alterações. Guaíra e Tape são contemporâneas temporalmente.

Esses aldeamentos, chamados de Missões ou Reduções, das últimas décadas do século XVI até meados do século XVII, foram acossados por bandeirantes paulistas e por encomenderos de Assunção. A partir de 1641, após a vitória guarani sobre os bandeirantes na Batalha do M'Bororé (a legislação espanhola passa a ser mais firme contra a atuação dos tais encomenderos), as Missões Guarani passam por um grande estágio de desenvolvimento, onde prosperava a produção agropecuária e manufatureira; também, em especial, a produção de gado vacum, cultivo de erva-mate e confecção de produtos têxteis. Entretanto não só nas Reduções viviam os nativos. Diferentes grupos indígenas habitavam o território do Rio da Prata.

Os Guarani são também conhecidos nos escritos históricos como Arachanes (Guarani, moradores da região de Arasá, margem oeste da Laguna dos Patos, segundo a documentação jesuítica castelhana do século XVII) ou Patos (denominação portuguesa, também do século XVII, aos Guarani habitantes da Laguna do Patos, à qual emprestaram seu 
etnônimo), Carijós (denominação portuguesa, dos séculos XVII e XVIII, aos Guarani habitantes do litoral atlântico desde o atual Rio Grande do Sul até o Vale do Ribeira, no atual estado de São Paulo) e Tapes (sinônimo português para Guarani do atual Rio Grande do Sul - que é utilizado principalmente nos séculos XVII e XVIII, períodos em que o território do Rio Grande do Sul foi denominado Província do Tape, como referido - que significa caminho em guarani).

As primeiras sesmarias datam do início da colonização portuguesa no Rio Grande de São Pedro. Mas, a partir da Guerra Guaranítica, cresceu a concessão de terras no extremo sul da América portuguesa. Inicialmente, as primeiras sesmarias foram doadas para assegurar a posse do território ocupado, a saber, Rio Grande, Rio Pardo e Viamão. Na segunda metade do século XVIII, com a reconquista de Rio Grande ${ }^{25}$, a expansão lusitana tomou novo impulso, e até o início do século XIX, o futuro estado do Rio Grande do Sul teve praticamente os seus limites geográficos configurados como os que conhecemos hoje ${ }^{26}$. Essa expansão verificada durante a segunda metade do século XVIII foi acompanhada com a concessão de sesmarias em direção ao sul em territórios recém-incorporados à colônia portuguesa, abrindo assim novas frentes de expansão.

Em 1780 a região onde atualmente localizam-se as cidades de Eldorado do Sul, Guaíba e Barra do Ribeiro (entre outras) aparecem oficialmente nos registros públicos como extensas sesmarias, doadas pela coroa portuguesa no intuito de colonizar a porção territorial conhecida como Brasil Meridional. Em 1732, Jerônimo de Ornelas Menezes, português da ilha da Madeira, fixou-se na região leste do Lago Guaíba, mais precisamente na atual cidade de Viamão (Campos de Viamão). Além de Jerônimo, mais dois sesmeiros receberam terras nesse local e posteriormente fundaram a "Freguesia de Porto dos Casais", primeira nominação para cidade de Porto Alegre. Cerca de cinquenta anos depois, a outra margem também recebe incentivo da coroa para povoamento.

\footnotetext{
${ }^{25}$ Em 1762, os espanhóis conquistam a vila de Rio Grande. E em 1776, os lusitanos expulsam os invasores.

${ }^{26}$ Em 1801, as Missões Orientais são conquistadas pelos portugueses. Apenas uma pequena parte do território, perto de Barra do Quaraí, ficou em litígio.
} 
A "Freguesia de Pedras Brancas de Nossa Senhora do Livramento", depois chamada de Guaíba, é dividida em glebas entre onze estancieiros. Nas duas margens do Lago, as Freguesias têm comunicação através da navegação, ativada pelo comércio e pelo desenvolvimento urbano de ambos os lados. Enquanto Porto Alegre cresce como polo para atividades de comércio e também passa a ganhar importância política, Guaíba facilita a expansão da colonização para a região central do estado. Abaixo, mapa ilustrativo das primeiras sesmarias de Pedras Brancas (Guaíba).

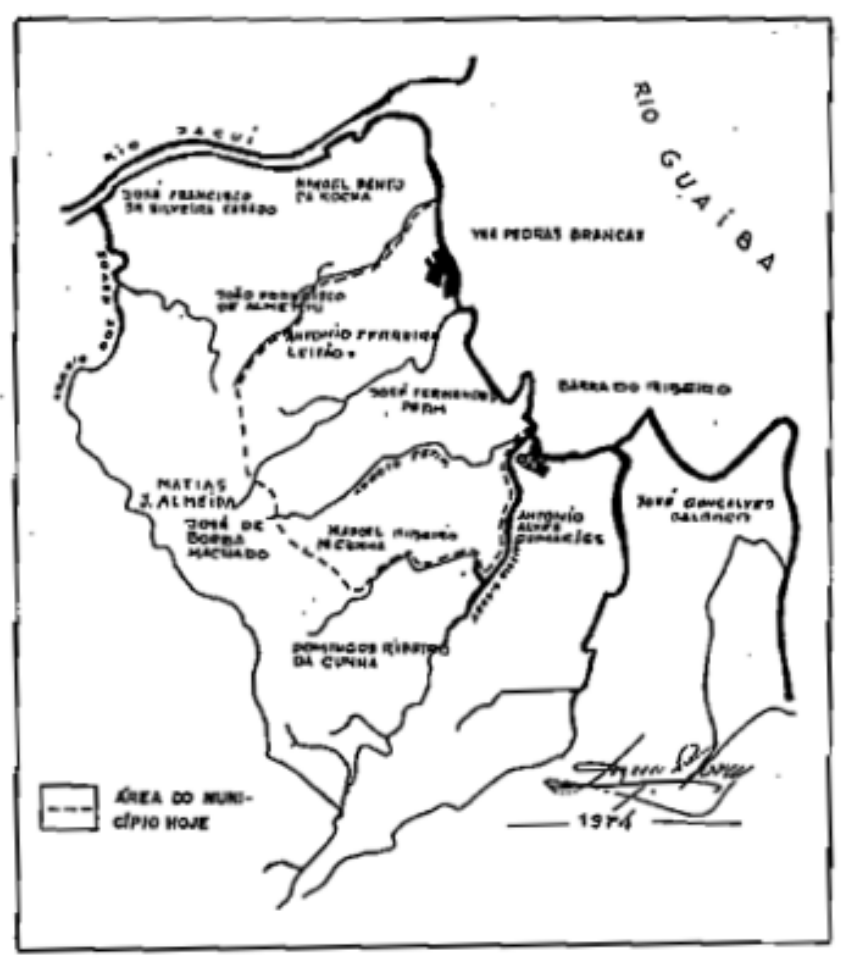

Ao norte o Rio Jacuí, a leste o Guaíba, a oeste, como afluente do Jacuí, o Arroio dos Ratos; e entrecortando a imagem temos quatro Arroios identificados como Arroio do Conde, Arroio Passo Fundo, Arroio Petim, Arroio Passo Grande (ou Capivara) e Arroio Ribeiro.

Os onze sesmeiros eram: José Francisco da Silveira Casado, Manoel Bento da Rocha, José Francisco de Almeida, Antonio Ferreira Leitão, José Fernandez Petim, Matias J. Almeida, José de Borba Machado, Manoel Ribeiro da Cunha, Domingos Ribeiro da Cunha, Antonio Alvez Guimarães e José Gonçalves Salgado.

IMAGEM 08. Mapa de localização dos primeiros sesmeiros (WORM, 1974, p. 41).

O panorama percorrido até aqui traz luz à compreensão do contexto de fundação da "Freguesia das Pedras Brancas de Nossa Senhora do Livramento", em 17 de fevereiro de 1857, pelo presidente da Província de São Pedro do Rio Grande do Sul, Jerônimo Coelho, através da Lei $n^{\circ} 358$.

No período imperial, segundo Worm (1974), os primeiros imigrantes a chegarem à Freguesia eram de origem polonesa e alemã, responsáveis por fundar as colônias de Mariana Pimentel e Sertão 
Sant `Ana. Patrocinando a imigração, o Governo Imperial de D. Pedro II chegou a publicar nos jornais europeus um chamado conclamando colonos a virem para o sul do Brasil, tamanha sua preocupação em povoar a região.

A criação de gado torna-se uma das principais atividades econômicas desde os primeiros tempos de povoamento. Na atualidade, principalmente a pecuária de gado bovino possui grande importância econômica para região, juntamente com as indústrias de papel, com destaque para produção de celulose. Na agricultura, as lavouras de arroz destacam-se. Pode-se afirmar que a atual paisagem da região mostra-se preenchida pelos campos com gado bovino, grandes lavouras de arroz e extensas plantações de eucalipto.

O Século XIX é particularmente decisivo para a mudança na vida dos indígenas em território do Brasil meridional. Período em que se consolidou a ocupação luso-brasileira no território do Rio Grande do Sul, foi este marcado por diversas guerras: lutas pela independência e de autonomia, quase todos os conflitos envolveram diretamente a população indígena do Rio Grande do Sul, em especial a guarani. A constituição dos Estados Nacionais platinos e as sucessivas batalhas ocorridas entre as facções políticas locais contribuíram para o clima tenso na região ${ }^{27}$. Durante as primeiras três décadas do século XIX, as Missões (orientais e ocidentais) foram saqueadas diversas vezes 28 .

\footnotetext{
${ }^{27}$ Em 1808, Napoleão invadiu a Espanha e destituiu o Imperador. Rapidamente as elites coloniais reuniram-se em oposição à invasão. A grande discussão dos colonos, porém, centrava-se no tipo de relação em que estabeleceriam a partir da restauração em 1810: retornava-se ao centralismo metropolitano ou as colônias passariam a gozar de grande autonomia política e econômica. Dessa querela, resultaram as guerras de independência das colônias espanholas na América Latina. Devido às divergências entre as facções dos colonos, o Vice-Reinado do Rio da Prata desmembrou-se em quatro países independentes: Argentina (1816), Paraguai (1811), Uruguai (1828) e Bolívia (1825). Uma vez estabelecidos os Estados nacionais, as facções políticas passaram a disputar o controle do poder de forma violenta, particularmente no Uruguai e na Argentina.

${ }^{28}$ Em 1801, houve a guerra de conquista das Missões. Nesse conflito, luso-brasileiros expulsam os espanhóis e expandem seus domínios no oeste do atual Rio Grande do Sul. Em represália às investidas de Artigas, a partir de 1811, às Missões Orientais (os Sete Povos), o comandante da Província de Missões, brigadeiro Francisco das Chagas Santos, invadiu o território das missões ocidentais, destruindo os seus edifícios e saqueando os seus bens, principalmente os ornamentos das igrejas. Estes ornamentos foram,
} 
Temendo a 'Revolução Artiguista' na Banda Oriental, entre 1811 e 1820, o Império Brasileiro interveio militarmente no Prata, ocasionando um série de revoltas contra sua presença. Após a anexação ao Império brasileiro, sob o nome de Província Cisplatina (1821), o Uruguai iniciou a luta pela sua independência em 1825, conseguindo-a em 1828 na chamada Guerra da Cisplatina. Entre 1835 e 1845, no Rio Grande do Sul, ocorreu a maior guerra civil da história brasileira: a Revolução Farroupilha. Entre 1849 e 1850 ocorrem diversas revoltas populares no norte do Uruguai. Essas rebeliões, chamadas de Califórnia, questionavam a presença de estancieiros brasileiros no Uruguai29. Estes, por sua vez, sufocaram as rebeliões com a ajuda de forças legais uruguaias. Em 1851 e 1852 o Brasil declarou guerra contra Rosas, presidente argentino. Nesse conflito, a totalidade da cavalaria foi composta por rio-grandenses, entenda-se índios e negros. Entre 1865 e 1870 eclodiu a Guerra do Paraguai, maior conflito armado da história da América do Sul. Embora entre a Guerra do Paraguai e a Revolução Federalista (1893-1895) haja 23 anos de paz, esta foi relativa. A crescente rivalidade entre as facções políticas existentes no Estado criava um clima de medo e desconforto, pois a violência foi a tônica desses anos, assim como o intervalo de tempo entre um conflito e outro. Concomitante, houve crescente violência contra os indígenas, fizessem eles parte de aldeias reconhecidas pelo Estado ou não, principalmente sobre suas terras.

Esses conflitos explicam a realidade atual das populações indígenas no Rio Grande do Sul, em particular, e no âmbito geral na bacia platina. Diversos dos documentos aqui citados revelam a profunda relação entre os Guarani e as guerras que eclodiram no sul-rio-grandense, mostrando a importância do contingente indígena e informando a circulação destes pelo território então em disputa. $O$ esbulho do espaço ocupado pelos Guarani deu-se, como podemos ver, respaldado pela legislação indigenista do Império brasileiro.

Tomando como exemplo um relatório encaminhado ao Presidente da Província do Rio Grande do Sul, o Conselheiro Dr. Antão Fernandes

posteriormente, distribuídos entre as igrejas da capitania Rio Grande do Sul. Em 1828, as Missões Orientais foram novamente saqueadas pelo General Uruguaio Fructuoso Rivera (PORTO, 1943. p. 524).

${ }^{29}$ De acordo com Souza e Prado (2004), cerca de $30 \%$ do norte do Uruguai era ocupado por estancieiros brasileiros. 
Leão, em 27 de julho de 1861, o então Diretor Geral dos Índios, Brigadeiro José Joaquim de Andrade Neves, aponta informações interessantes sobre a atuação e circulação dos Guarani pelo território da Província. Expondo ao Presidente a situação dos quatro aldeamentos oficiais sob sua direção (Nonoai e Santa Isabel, de índios Kaingang e Xokleng, e São Nicolau e São Vicente, de Guarani), Andrade Neves relata que o Aldeamento de São Nicolau ${ }^{30}$ seria melhor aproveitado se reunisse

núcleo os índios dispersos pela extinção de dois dos aldeamentos da Província [um deles o Aldeamento de São Vicente, situado no Rincão de São Vicente, município de São Gabriel]. Em ótimas terras, na concorrência das colônias que the ficam vizinhas, teriam os índios com um regulamento que os tivesse sob uma séria disciplina, sem dúvida uma vida muito útil a si, à Província e, quiçá, ao País $[\ldots]^{31}$.

Sobre o Aldeamento de São Vicente, o Diretor Geral diz que em "três anos incompletos, existiu este aldeamento e sob as melhores esperanças teria vivido uma vida de progresso e utilidade se o "choque das paixões políticas não tivesse ali encontrado meios para sua destruição". Ao final do documento, Andrade Neves tenta sensibilizar o Presidente sobre a situação dos índios sob sua direção com os seguintes argumentos:

Companheiro, muitas vezes na guerra destes nossos bravos patrícios, tenho conhecido [índios] que tem uma natural paixão pela vida das armas; ali seria eles a um tempo lavradores e soldados, teriam o exemplo de nossas tropas para exercitá-los, achariam nas necessidades da vida 'inventivo' para o trabalho e [ilegível] de suas terras; além de guardas da fronteira ${ }^{32}$.

\footnotetext{
${ }^{30}$ Em relatório apresentado em 1852, o Diretor Geral dos Índios informa que "a de cadência dos aldeamentos, principalmente o de São Nicolau, é em razão de se ter recrutado para o Exército, assim como na Revolução porque passou esta Província, ambos os partidos tiraram os índios para as armas e à penúria que ficaram reduzidos, tiveram de emigrar para diferentes pontos da Província". AHRS - Índios maço 4 - Diretoria Geral de Índios - Correspondência ativa - 1851 - Cópia do Relatório apresentado ao Ministro do Império - 29/12/1851.

${ }^{31}$ AHRS - Índios - maço 4 - Diretoria Geral de Índios - Correspondência ativa - 1861.

32 AHRS - Índios - maço 4 - Diretoria Geral de Índios - Correspondência ativa - 1861. O 'deslocamento' de grupos indígenas inteiros tinha respaldo jurídico.
} 
Desse relatório nota-se a dispersão dos Guarani pelo território e algumas possíveis causas relacionadas entre si: a guerra e o serviço militar ${ }^{33}$. Da correspondência de Andrade Neves percebe-se a participação de indígenas nos conflitos, tanto nacionais como regionais. Comandante militar com larga experiência de guerra, Andrade Neves reconhece a bravura dos Guarani nos serviços prestados ao exército e recomenda que os mesmos sejam deslocados para a fronteira, palco de inúmeras querelas e um território em latente estado de tensão com as repúblicas vizinhas. Porém por trás do desejo que os 'bravos Guaranis' dirigissem-se aos postos fronteiriços e defendessem a pátria, escondiase o desejo de utilizar as terras do Aldeamento para outro propósito. No ano seguinte, em nova correspondência enviada ao Presidente da Província, Andrade Neves explicaria um pouco melhor o que seria o dito 'choque das paixões políticas' que destruiu o Aldeamento de São Vicente, contribuindo, assim, para a dispersão dos indígenas no Estado.

Se Andrade Neves atestava a bravura guarani no combate a serviço da pátria, na carta de 27 de julho de 1861 o Diretor Geral dos Índios fala sobre $o$ 'choque das paixões políticas' que trouxe sérias consequências aos Guarani. Em um relatório datado em 12 de abril de 1862, assinado pelo Diretor do Aldeamento de São Nicolau, Joaquim José da Fonseca Souza Pinto, e pelo próprio Brigadeiro José Joaquim de Andrade Neves Pinto, Diretor Geral dos Índios da Província, foi explicado o que seria esse 'choque das paixões políticas'. Andrade Neves iniciou a carta fazendo um breve histórico do Aldeamento

Fui nomeado em 02/1846 pelo Exmo Marquês de Caxias, então Presidente e Comandante em Chefe do Exército, para tomar conta dos emigrados orientais que nessa época se acontonaram nesta Aldeia, passando depois a ser nomeado por V.Exa Diretor da mesma, com a aprovação do mesmo Exmo Marquês de Caxias [futuro Duque de Caxias]. Em 1819 exerci o emprego de Comandante Militar do mesmo Aldeamento por determinação do finado Visconde de Pelotas. Referindo-

\footnotetext{
33 Em Relatório apresentado em 1852, o Diretor Geral dos Índios informa que "a decadência dos aldeamentos, principalmente o de São Nicolau, é em razão de se ter recrutado para o Exército, assim como na Revolução porque passou esta Província, ambos os partidos tiraram os índios para as armas e à penúria que ficaram reduzidos, tiveram de emigrar para diferentes pontos da Província." AHRS - Índios maço 4 - Diretoria Geral de Índios - Correspondência ativa - 1851 - Cópia do Relatório apresentado ao Ministro do Império - 29/12/1851.
} 
me ao tempo do meu Comando, preciso é declarar que não tendo recebido o cadastro do Aldeamento, não me é possível referir-me oficialmente à época remota de sua fundação, nem alcançar informações a esse tempo dignas de crédito. Este Aldeamento foi criado em 1763, a julgar por um abaixo assinado feito em 1813 ao Capitão General D. Diogo de Souza, no qual alegando seus direitos, apontavam 50 anos de fundação do Aldeamento, e segundo o assentamento de um livro antigo desse tempo, rubricado pelo finado Governador José Marcelino de Figueiredo, datado do ano de $1771^{34}$.

Não padece dúvida a Tribo Guarani foram os fundadores deste Aldeamento vindos dos antigos povos de Missões para este ponto. A experiência de muitos anos mostra que esta Tribo é de boa índole, de vida à educação religiosa que receberam dos Jesuítas, pelos quais foram catequizados ${ }^{35}$.

A partir deste ponto, Andrade Neves passa a relatar sua experiência no Aldeamento, trazendo muitas informações que colaboram para a compreensão da dispersão dos Guarani.

Quando em 1819 tomei o Comando deste Aldeamento ainda existiam cerca de 300 a 400 aldeados, conservando-se em ordem e moralidade até 1835, época em que quando rebentou a Revolução nesta Província. Esta Revolução veio dar o golpe mortal a este Aldeamento, as forças da legalidade chagaram às armas, do lado dos revoltosos fizeram o mesmo, reunindo ambos para as fileiras, e a proporção que a guerra se foi alongando, vencidos combates de parte a parte, a juventude sem defesa, e assim mesmo foram cruelmente arrastados por ambas as forças de forma que só restando as mulheres, estas impedidas pela dura lei da necessidade tiveram de tomar o partido desesperado de seguirem a sorte de seus pais, maridos e filhos internando-se pela Campanha, onde muitas pereceram e dos que escaparam ficaram nela 'preexistindo', de forma que bem poucas voltaram ao lugar de seu domicílio. Foco de passagem o ano de 1846 em que estiveram submetidos ao meu Comando 297 emigrados vindos do Estado Oriental que, por ordem do mesmo Exmo Marquês [de Caxias, futuro

\footnotetext{
${ }^{34}$ AHRS - Índios - maço 4 - Diretoria Geral de Índios - Correspondência ativa - 1862. Relatório do Estado do Aldeamento de São Nicolau, ao Sr. Diretor Geral dos índios em 12 de abril de 1862.

${ }^{35}$ AHRS - Índios - maço 4 - Diretoria Geral de Índios - Correspondência ativa - 1862. Relatório do Estado do Aldeamento de São Nicolau, ao Sr. Diretor Geral dos índios em 12 de abril de 1862.
} 
Duque de Caxias], foram acantonados nesse ponto, percebendo 'etapes' por conta da Fazenda Nacional, e logo que Ihe foram suspensas em novembro do mesmo ano se dispersaram para a Fronteira, ficando unicamente aqueles que por avançada idade e moléstia estavam privados de seguirem a sorte de seus companheiros, e desta sorte concluiu-se a emigração. O índio Guarani é favorecido de habilidade para as artes, e ainda melhores disposições se encontram neles para o serviço das armas, isto se tem provado em todos os tempos de campanha e V.Exa o pode atestar porque o tem ${ }^{36}$.

Finalizando, recomenda

Quanto não seria proveitoso a esta Aldeia e como chamaria a ela os índios dispersos se o Governo se dignasse socorrê-la todos os anos com a quantia de 2:000\$ para a conservação de sua Aldeia e Igreja. Sustentação e vestuário dos decrépitos que tantos serviços prestaram à Nação e seus filhos continuam a prestar!..que sacrifício seria este feito a favor dos Senhores Primários e naturais de todo o Brasil, hoje elevado à categoria de Império; e bem diziam a Mão Augusta que os protegia. Passam-se meses que se não celebra uma missa, e quando acontece haver a de 'alguma' promessa ou por intenção de defuntos e sendo estes moradores pobres, nem todos podem ocorrer à Matriz do Rio Pardo, que está à distância de $3 / 4$ de légua, é esta também uma das causas que tem concorrido para a decadência deste lugar, digno de melhor sorte 37 .

De todas as informações passadas, no presente momento atentaremos à passagem da Revolução Farroupilha. Andrade Neves informa que até 1835 a vida no Aldeamento transcorria com certa normalidade, mas após a Revolução de 1835 a situação mudou substancialmente. De acordo com seu depoimento, os Guarani lutaram em ambos os lados do conflito, acarretando como consequência um incremento na dispersão indígena e, conforme a carta de 27 de julho de

\footnotetext{
${ }^{36}$ Ver o resto do documento. AHRS - Índios - maço 4 - Diretoria Geral de Índios - Correspondência ativa - 1862. Relatório do Estado do Aldeamento de São Nicolau, ao Sr. Diretor Geral dos índios em 12 de abril de 1862.

${ }^{37}$ AHRS - Índios - maço 4 - Diretoria Geral de Índios - Correspondência ativa - 1862. Relatório do Estado do Aldeamento de São Nicolau, ao Sr. Diretor Geral dos índios em 12 de abril de 1862.
} 
1861, com a extinção do Aldeamento de São Vicente. Essa informação não deixa de ser surpreendente. A Revolução Farroupilha é, sem dúvidas, o evento histórico mais trabalhado e discutido na formação histórica e cultural do Rio Grande do Sul, mas diversos especialistas no tema simplesmente 'apagam' do conflito a presença indígena.

O médico, político, fazendeiro e militar José Gomes de Vasconcellos Jardim, morador de Pedras Brancas (primeira designação para as atuais cidades de Guaíba, Eldorado do Sul e Barra do Ribeiro), era uma das principais lideranças farroupilhas: em sua casa fora arquitetada a invasão de Porto Alegre, foi Presidente da República Rio-Grandense e em sua residência faleceu o líder Bento Gonçalves, em 1847. Gomes Jardim, então líder farrapo, utilizou-se de um dos principais expedientes usados em larga escala no período para cooptar índios à sua causa: o bom tratamento, principalmente às lideranças.

Sendo uma região de fronteira, desde o Século XVIII a população nativa era pensada como súditos em potencial, passíveis de aumentarem as forças portuguesas em suas disputas com os espanhóis. Este 'bom tratamento' se materializava em uma série de privilégios e distinções concedidos aos indígenas e às suas aldeias (GARCIA, 2007). Tal lógica se fazia presente ainda no século XIX. O contingente indígena não podia ser desprezado para a batalha e Gomes Jardim - e outros militares - sabia disso. Portanto era preciso atrair os nativos. Um dos principais estratagemas utilizados era o apadrinhamento.

Em uma sociedade profundamente hierarquizada, com pouquíssimas possibilidades de ascensão, as relações de apadrinhamento e compadrio assumiam-se como relações sociais importantíssimas na medida em que, para o afilhado pobre, ter um padrinho rico, influente e com prestígio significava ter uma proteção necessária: ou contra a opressão e perseguição de agentes da lei, ou contra desentendimentos com outros grupos poderosos, ou mesmo para a obtenção de privilégios. No caso de um afilhado rico, o padrinho assumia a posição de um possível 'encaminhador' do jovem no mundo social. Em contrapartida, os afilhados e seus pais (compadres) deveriam prestar lealdade ou 'serviços' ao padrinho, aumentando seu prestígio e seu poder. Os afilhados e compadres pobres, geralmente, prestavam seus serviços em trabalhos para o padrinho e compadre, ou mesmo o 
auxiliava em caso de conflito; ao afilhado rico, competia 'alavancar' o nome de seu padrinho dentro da esfera política e social, bem como aumentar sua influência em círculos de poder. Tal prática é verificada pelo menos até as primeiras décadas do século XX. Dessa forma é que entende-se por que em 31 de março de 1850, no Oratório de Nossa Senhora do Livramento, Freguesia de Pedras (atuais cidade de Guaíba, Eldorado do Sul e Barra do Ribeiro), o líder farrapo José Gomes de Vasconcellos Jardim e sua mulher, Isabel Leonor Ferreira Jardim, foram padrinhos da "inocente" Luciana, nascida em 30 de julho de 1849, filha legítima dos indígenas Guarani José Ignácio (natural de São Gabriel) e Cândida Antônia (natural de Alegrete), neta paterna dos Guarani José Cardoso e Maria Paula (naturais das Missões) e neta materna dos Guarani Miguel Antônio e Isabel de Tal (naturais das Missões) ${ }^{38}$. Ao que tudo indica, o Guarani José Ignácio lutara junto com Gomes Jardim na Revolução Farroupilha. O apadrinhamento de sua filha e o compadrio resultante do batismo era a reafirmação de uma relação estabelecida entre os dois 39 .

Gomes Jardim faleceu em 1854 e a partir desta data até o final do século XIX não são encontrados registros paroquiais de indígenas Guarani em Pedras Brancas ${ }^{40}$. Somente são encontradas referências a indígenas na região oeste da Lagoa dos Patos/Lago Guaíba em registros policiais e/ou judiciais, somada com outras observações sobre a circulação guarani pelo amplo território do Brasil Meridional ${ }^{41}$.

\footnotetext{
${ }^{38}$ Arquivo Histórico da Cúria Metropolitana. Guaíba - Livro 1 B. Folha 88R.

${ }^{39}$ Para o século XVIII "O batismo era um parentesco ritual, capaz de criar laços entre grupos de níveis sociais distintos. No entanto, o apadrinhamento também funcionava como uma distinção entre os índios, na medida em que apenas alguns [...] usufruiriam deste benefício. Dessa forma, ao apadrinhar os índios, o governador estaria lhes concedendo uma distinção, a ser usada também como um importante elemento de hierarquia social, pois apenas alguns casais teriam o privilégio de possuírem laços simbólicos não apenas com o governador, mas também com o vice-rei". No século XIX o padrão continua (GARCIA, 2007, p $88)$.

${ }^{40}$ Apenas no $1^{\circ}$ Livro de Batismos de Guaíba (1842-1852) são encontrados registros de Guarani em Pedras Brancas: 6 batismos e 1 casamento.

${ }^{41}$ Saint-Hilaire reforça a circulação transnacional dos Guarani, quando diz que no Brasil "Vários prisioneiros a quem interroguei disseram-me serem paraguaios [Paraguai], e que trabalhavam como peões na Província de Entre-Rios [Argentina], tendo sido obrigados por Artigas [Uruguai] a pegar em armas. É muito provável que esta gente esteja mentindo e que tenha acompanhado seu chefe na esperança de praticarem a pilhagem" (SAINT-HILAIRE, 1999). A menção a Entre-Rios é bastante recorrente nos escritos desse autor e diz respeito a uma Província Argentina que ainda nos dias contemporâneos abriga aldeias guarani.
} 
Em Nhüu Poty, os Mbyá contaram com a anuência de um proprietário não indígena para construírem moradias no interior de suas terras, mais precisamente para ocuparem sete de seus hectáres. No ano de 2010, quando em curso os trabalhos de campo para estudo de identificação e delimitação da Terra Indígena pela FUNAI, o proprietário solicitou aos Mbyá que assinassem Instrumento Particular de Comodato, no qual constam nove cláusulas a respeito da presença indígena em suas terras. Alguns Guarani prestam serviços ao proprietário, trabalhando em sua vinícola e em suas lavouras, sendo remunerados para tanto. Essa aliança firmada por força das circunstâncias possibilitou aos Mbyá permanecerem e ocuparem parte do território reivindicado; no entanto, quando em cena o processo de regularização fundiária, as relações até então tranquilas incitaram reflexões de ambos os lados: o proprietário, por sentir-se ameaçado de "perder" suas terras, exigiu a assinatura do documento citado na tentativa de formalizar o acordo estabelecido verbalmente há dez anos; os Mbyá, por dependerem em várias instâncias de uma relação não conflituosa com o proprietário, assinaram o documento mesmo sem saberem ao certo do que se tratava, temerários mas também ansiosos pela continuação dos estudos para reconhecimento de seus direitos constitucionais. Sabendo que o processo de regularização da Terra Indígena pode levar décadas ou quiçá nunca acontecer em definitivo, os Mbyá firmaram o documento e atenderam a todas as exigências demandadas a fim de permanecerem no local42.

Trata-se de uma situação particular, que difere-se das demais ocupações referidas neste ensaio, mas não completamente estranha a outras situações vividas pelos Mbyá em seu vasto território. No que tange ao estado do Rio Grande do Sul, como registrado em páginas anteriores, vale lembrar o histórico de delimitação de fronteiras tardio, no qual os Guarani participaram ativamente guerreando e servindo de mão de obra aos brancos. A historiografia recente mostra também conflitos envolvendo indígenas e imigrantes alemães e italianos, que

\footnotetext{
${ }^{42}$ Cópia do referido documento foi entregue ao Ministério Público Federal e também anexado ao relatório de identificação e delimitação da Terra Indígena Nhüu Poty.
} 
receberam terras do estado, justamente em espaços ocupados por povos nativos (SEYFERTH, 1982). Afora reforma agrária realizada no norte do estado na década de 1960, que assegurou títulos de terras a proprietários brancos expropriando indígenas Kaingang e Guarani43.

Pois o exemplo trazido sobre Nhüu Poty permite não somente apreender a dimensão da relação cotidiana 'juruá proprietário' - 'mbyá em situação de beira de estrada', como também contextualizar os desafios encontrados na regularização fundiária: o proprietário branco tem o título da terra, e os dados de esbulho territorial necessários ao reconhecimento dos direitos indígenas não serão encontrados pontualmente nessa situação. Significa dizer que é através de uma análise diacrônica da presença indígena na região e principalmente da política de povoamento por europeus e descendentes, promovida pelo estado em diferentes épocas da história (WORM, 1974; SEYFERTH, 1982), que podemos nos aproximar de uma maior compreensão do que se passa nos dias de hoje.

A pesquisa de campo, embasada pelas narrativas mbyá sobre sua presença na região, quando em consonância com as fontes levantadas, ganha maior pertinência. Como trata-se de um ensaio que intenta resumir estudos realizados para fins de elaboração de relatórios de identificação e delimitação de terra pela FUNAl, muitas informações foram subtraídas e talvez tenhamos deixado de fora dados importantes. De todo modo, a intenção era evidenciar a presença indígena na Bacia Hidrográfica do Guaíba, seja através de escritos e fontes ou narrativas levantadas através de etnografia, ressaltando que há relevância em sistematizar informações dispersas e assim tirar consequências reflexivas sobre o modo de ocupação mbyá-guarani contemporâneo face à complexidade da relação estabelecida e por vezes evitada com os brancos.

\section{Referências bibliográficas}

\footnotetext{
${ }^{43}$ Durante o governo de Leonel Brizola.
} 
AMBROSETTI, Juan. Los indios Cainguá del Alto Paraná (Misiones). Boletin del Intituto Geográfico Argentino, Bueno Aires, v. 15, p. 661-744, 1895.

ASSIS, Valéria. Dádiva, mercadoria e pessoa: as trocas na constituição do mundo social Mbyá-Guarani. 2006. 326 f. Tese (Doutorado em Antropologia Social) Universidade Federal do Rio Grande do Sul, [2006].

BARCELlOS, Arthur H. F. O Compasso e a Cruz. Cartografia Jesuítica da América Colonial. Porto Alegre: Strat Design, 2006. 1 CD-ROM.

BROCHADO, José Proenza. Desarrollo de la tradición cerámica Tupiguarani (A. D. 500-1800). In: Simpósio Nacional de Estudos Missioneiros, 1., 1975. Anais..., Santa Rosa: FFCLDB, 1975. p. 76-154.

An ecological model of the spread of pottery and agriculture into Eastern South America. 1984. 1014 f. Tese (Doutorado em Antropologia) - University of Illinois, [1984].

A expansão dos Tupi e da cerâmica policrômica amazônica. Dédalo, São Paulo, n. 27, p. 65-82, 1989.

CADOGAN, León. Ayvu Rapyta: Textos míticos de los Mbyá-Guaraní del Guairá. São Paulo: USP, 1997.

CANABraVA, Alice. O Comércio Português no Rio da Prata (1580-1640). São Paulo: USP, 1944.

CLASTRES, Hélène. Terra sem mal: o profetismo Tupi-Guarani. São Paulo: Brasiliense, 1978.

CUNHA, Manuela Carneiro da. Política indigenista no século XIX. In: História dos Índios no Brasil. São Paulo: Companhia das Letras, 1992. p. 133-154.

GARCIA, Elisa Frühauf. A integração das populações indígenas nos povoados coloniais no Rio Grande de São Pedro: legislação, etnicidade e trabalho. 2003. 162 f. Dissertação (Mestrado em História) -Universidade Federal Fluminense, [2003].

As diversas formas de ser índio: políticas indígenas e políticas indigenistas no extremo sul da América portuguesa. 2007. 305 f. Tese (Doutorado em História) Universidade Federal Fluminense, [2007].

GARLET, Ivori José. Mobilidade Mbya: História e Significação. 1997. 229 f. Dissertação (Mestrado em História Ibero-Americana) - Pontifícia Universidade Católica do Rio Grande do Sul, [1997].

GONÇALVES, Marcelo. Ethos e movimento: um estudo sobre mobilidade e organização social mbyá guarani no litoral sul do Brasil. 2011. 139 f. Dissertação (Mestrado em Antropologia Social) - Universidade Federal do Paraná, [2011]. 
GUZMÁN, Ruiz. Argentina Manuscrita. Asunción, 1612.

MÉTRAUX, Alfred. Les Migrations Historiques des Tupi-Guarani. Journal de la Societé des Américanistes, Nanterre, n. 19, p. 1-45, 1927.

MONTEIRO, John Manuel. Os Guarani e a História do Brasil Meridional (Século XVIXVII). In. CUNHA, Manuela Carneiro da. História dos Índios no Brasil. São Paulo:Companhia das Letras, 1992. p. 475-498.

NIMUENDAJU, Curt Unkel. Mapa etno-histórico de Curt-Nimuendaju. Rio de Janeiro: IBGE/Fundação Nacional Pró-Mémoria, 1981.

As lendas da criação e destruição do mundo como fundamento da religião dos Apapocúva-Guarani. São Paulo: Hucitec/Edusp, 1987.

NOELLI, Francisco. Sem Tekohá não há Tekó: em busca de um modelo etnoarqueológico da subsistência e da aldeia guarani aplicado a uma área de domínio no delta do Jacuí- RS. 1993. 488 f. Dissertação (Mestrado em História) - PUCRS, [1993].

PORTO, Aurélio. História das Missões Orientais do Uruguai. Rio de Janeiro: Ministério da Educação e Saúde, 1943.

PRADO, Fabrício Pereira. Colônia do Sacramento: o extremo sul da América portuguesa no século XVIII. Porto Alegre: F.P.P., 2002.

RUSSELL-WOOD, Anthony John R. Um mundo em movimento: os portugueses na África, Ásia e América (1415-1808). Lisboa: DIFEL, 1998.

SAINT-HILAIRE, Auguste de. Viagem ao Rio Grande do Sul (1820-1821). Belo Horizonte: Ed. Itatiaia, 1999.

SEYFERTH, Geralda. Nacionalismo e Identidade Étnica: a ideologia germanista e o grupo étnico teuto-brasileiro numa comunidade do Vale do Itajaí. Florianópolis: Fundação Catarinense de Cultura, 1982.

SOUZA, Susana Blaiel; PRADO, Fabrício Pereira. Brasileiros na fronteira uruguaia: economia e política no século XIX. In: GRIJÓ, Luiz Alberto et al. Capítulos de História do Rio Grande do Sul. Porto Alegre: Editora da UFRGS, 2004. p. 121-146.

TESCHAUER, Carlos. História do Rio Grande do Sul dos dois primeiros séculos. Porto Alegre: Selbach, 1922. 3 v.

WORM, Fernando. Guaíba Terra e Povo. Porto Alegre: Livraria do Globo, 1974. 


\section{Fontes pesquisadas}

1. Depoimento de Roque Romero, espanhol que viveu 10 anos em Rio Grande, 14/11/1759. Información hecha por el Teniente Coronel y Mayor General del Ejército Don Diogo de Salas, de orden del Ex.mo Señor Don Pedro de Cevallos, Teniente General de los Reales Ejércitos, Governador y Capitán General de esta Província sobre la retención de los desertores españoles, sedución y extracción de Indios, robos y matanzas de ganado que han ejecutado los portugueses. Archivo General de Simanacas - Secretaria de Estado, Legajo 7405. Doc. $n^{\circ}$ 71. p. 6R.

2. Depoimento de Miguel Vidal, Alferes de Dragões do Presídio de Buenos Aires, 17/11/1759. Información hecha por el Teniente Coronel y Mayor General del Ejército Don Diogo de Salas, de orden del Ex.mo Señor Don Pedro de Cevallos, Teniente General de los Reales Ejércitos, Governador y Capitán General de esta Província sobre la retención de los desertores españoles, sedución y extracción de Indios, robos y matanzas de ganado que han ejecutado los portugueses. Archivo General de Simanacas - Secretaria de Estado, Legajo 7405. Doc. $\mathrm{n}^{\circ}$ 71. p. 11V.

3. Depoimento de Joseph Sánchez, soldado de Dragão do Corpo de Buenos Aires, 18/11/1759. Información hecha por el Teniente Coronel y Mayor General del Ejército Don Diogo de Salas, de orden del Ex.mo Señor Don Pedro de Cevallos, Teniente General de los Reales Ejércitos, Governador y Capitán General de esta Província sobre la retención de los desertores españoles, sedución y extracción de Indios, robos y matanzas de ganado que han ejecutado los portugueses. Archivo General de Simanacas - Secretaria de Estado, Legajo 7405. Doc. $n^{\circ}$ 71. p.13R.

4.

AHRS - Índios - maço 4 - Diretoria Geral de Índios - Correspondência ativa - 1848 Carta ao Presidente do Estada - 24/10/1848.

AHRS - Índios - maço 4 - Diretoria Geral de Índios - Correspondência ativa - 1849 Carta ao Diretor Geral dos Índios - 01/11/1849.

AHRS - Índios - maço 4 - Diretoria Geral de Índios - Correspondência ativa - Carta ao Presidente da Província - 10/04/1850.

AHRS - Índios - maço 4 - Diretoria Geral de Índios - Correspondência ativa - Carta ao Presidente da Província - 28/12/1850.

AHRS - Índios - maço 4 - Diretoria Geral de Índios - Correspondência ativa - Cópia de Relatório apresentado ao Ministro do Império - 29/12/1851.

AHRS - Índios - maço 4 - Diretoria Geral de Índios - Correspondência ativa - 1857 Carta ao Presidente da Província - 08/12/1857.

AHRS - Índios - maço 4 - Diretoria Geral de Índios - Correspondência ativa - 1858 Resposta ao Ofício do Governador - 15/07/1858. 
AHRS - Índios - maço 4 - Diretoria Geral de Índios - Correspondência ativa - 1858 Relatório ao Presidente da Província. 01/09/1858.

AHRS - Índios - maço 4 - Diretoria Geral de Índios - Correspondência ativa - 1859 Carta ao Presidente da Província - 08/10/1859.

AHRS - Índios - maço 4 - Diretoria Geral de Índios - Correspondência ativa - 1859 Relatório ao Presidente da Província - 17/03/1859.

AHRS - Índios - maço 4 - Diretoria Geral de Índios - Correspondência ativa - 1859 Informe ao Presidente da Província - 24/05/1859.

AHRS - Índios - maço 4 - Diretoria Geral de Índios - Correspondência ativa - 1859 Relatório ao Presidente da Província - 18/09/1859.

AHRS - Índios - maço 4 - Diretoria Geral de Índios - Correspondência ativa - 1861.

AHRS - Índios - maço 4 - Diretoria Geral de Índios - Correspondência ativa - 1861. Catequese e Civilização dos índios.

AHRS - Índios - maço 4 - Diretoria Geral de Índios - Correspondência ativa - 1861 Relatório ao Presidente da Província - 25/07/1861.

AHRS - Índios - maço 4 - Diretoria Geral de Índios - Correspondência ativa - 1862. Relatório do Estado do Aldeamento de São Nicolau, ao Sr. Diretor Geral dos índios em 12/04/1862.

AHRS - Índios - maço 4 - Diretoria Geral de Índios - Correspondência ativa - 1862. Diretor Geral acusando o recebimento de um ofício do Presidente da Província. 09/06/1862.

AHRS - Índios - maço 4 - Diretoria Geral de Índios - Correspondência ativa - 1863. Relatório Anual sobre os Aldeamentos.

AHRS - Índios - maço 4 - Diretoria Geral de Índios - Correspondência ativa - 1863. Carta de Andrade Neves respondendo ao Ofício sobre a demarcação enviado pelo Presidente da Província. 09/06/1862.

AHRS - Índios - maço 4 - Diretoria Geral de Índios - Correspondência ativa - S/Data.

5. Arquivo Histórico da Cúria Metropolitana. Guaíba - Livro 1 B. Folha 88R.

6. Jornal O Correio do Sul, $\mathrm{n}^{\circ} 37$ de 30 de julho de 1863.

7. "Translados do exame Corpo de Delito feito em éguas tosadas da marca de Viúva Azambuja \& Filhos”. Ano: 1866. Arquivo Público do Estado do Rio Grande do Sul. Comarca de Porto Alegre. Subfundo: Vara Cível e Crime. Datas limite: 01/01/1843 até /31/12/1930. Intervalo: 130 a 183. Doc. no 179. Folha 3R. Localização: Estante 142A - 
030.0154. Cód. Referência: Br/RS/PJ004/0006/0001/0001/0001 Br/RS/PJ004/0006/0003/0001/0001.

8. "Translados do exame Corpo de Delito feito em éguas tosadas da marca de Viúva Azambuja \& Filhos". Ano: 1866. Arquivo Público do Estado do Rio Grande do Sul. Comarca de Porto Alegre. Subfundo: Vara Cível e Crime. Datas limite: 01/01/1843 até 131/12/1930. Intervalo: 130 a 183. Doc. n 179. Folha 3V. Localização: Estante 142A 030.0154. Cód. Referência: Br/RS/PJ004/0006/0001/0001/0001 $\mathrm{Br} / \mathrm{RS} / \mathrm{PJ} 004 / 0006 / 0003 / 0001 / 0001$ 